\title{
Electric Training Aircraft in Colombia: A Review of Design, Manufacture and Feasibility
}

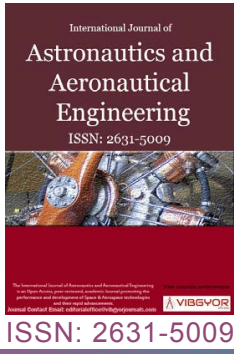

\section{Germán Wedge Rodríguez Pirateque ${ }^{1^{*}}$ and Yeinson Alfonso Castellanos Sanabria ${ }^{2}$}

\author{
${ }^{1}$ Germán Wedge Rodríguez Pirateque, Universidad Nacional de Colombia, Bogotá DC, Colombia \\ ${ }^{2}$ Yeinson Alfonso Castellanos Sanabria, Fundación Universitaria Los Libertadores, Bogotá DC, Colombia
}

\begin{abstract}
In the general aviation, the uses of the electrically powered engines allow the manufacture of new aircraft types with large benefits, such: More efficiency, low emission, easy maintenance, high reliability and low operational cost, which could improve flight times and training programs. The following review article studies the manufacture viability of an electric training aircraft in Colombia. For this, it is analyzed the possible challenges about the configurations and design requirements, systems and subsystems required, sensitivity studies, preliminary sizing and the services and capabilities required for Colombia. Thus, supported in these parameters, some proposals of the best sizing configuration and some recommendations to get ready the national industry in terms of infrastructure, regulation and agreements matters are showed. It will be an open engineering challenge with the opportunity to incorporate the Colombia's science and technology in the electric aircraft world market.
\end{abstract}

\section{Keywords}

Aircraft design, Aircraft manufacturing, Electric propulsion, More electric aircraft, Training aircraft

\section{Introduction}

Researches published by M.I.T $\mathrm{T}^{1}$ in the Environmental Research Letters ${ }^{2}$ [1] of IOP Publishing, say that commercial aviation produces $5 \%$ of the world environmental impact with the Jet-Fuel consumption [2,3], Figure 1 and Figure 2. For Colombia, according to the liquid fuel demand projection report by the MinEnergía ${ }^{3}$ and the UPME ${ }^{4}$, the average annual Jet Fuel consumption growth rate from 2016 year to the 2035 year will be $0.9 \%$, regarding $1.9 \%$ of gasoline and $2.4 \%$ of ACPM [4].
In the same way, according to the National Energy Plan 2020-2050 presented by the MinEnergía, the energy consumption will be $40 \%$ by the transport sector, where the aeronautic sector will contribute with $10 \%$ in that consumption. This information is perturbing within the current global political scenarios (Figure 2) with estimates of an increase in oil prices from 101 US\$/barrel in 2025 to 137 US\$/ barrel in 2040, due to the absence of fuel efficiency policies. This stimulates an energy transition to the electric mobility through strategies to mitigate environmental, social and economic repercussions

*Corresponding author: Germán Wedge Rodríguez Pirateque, Universidad Nacional de Colombia, Bogotá DC, Colombia

Accepted: May 21, 2020; Published: May 23, 2020

Copyright: (c) 2020 Pirateque GWR, et al. This is an open-access article distributed under the terms of the Creative Commons Attribution License, which permits unrestricted use, distribution, and reproduction in any medium, provided the original author and source are credited.

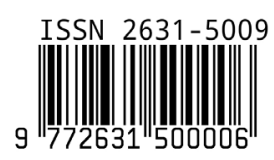

Pirateque and Sanabria. Int J Astronaut Aeronautical Eng 2020, 5:036 


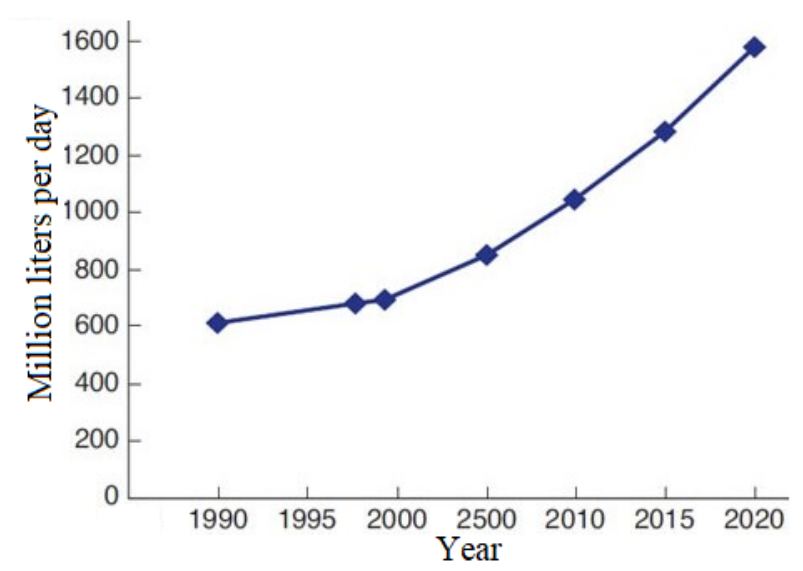

Figure 1: Jet fuel world consumption.

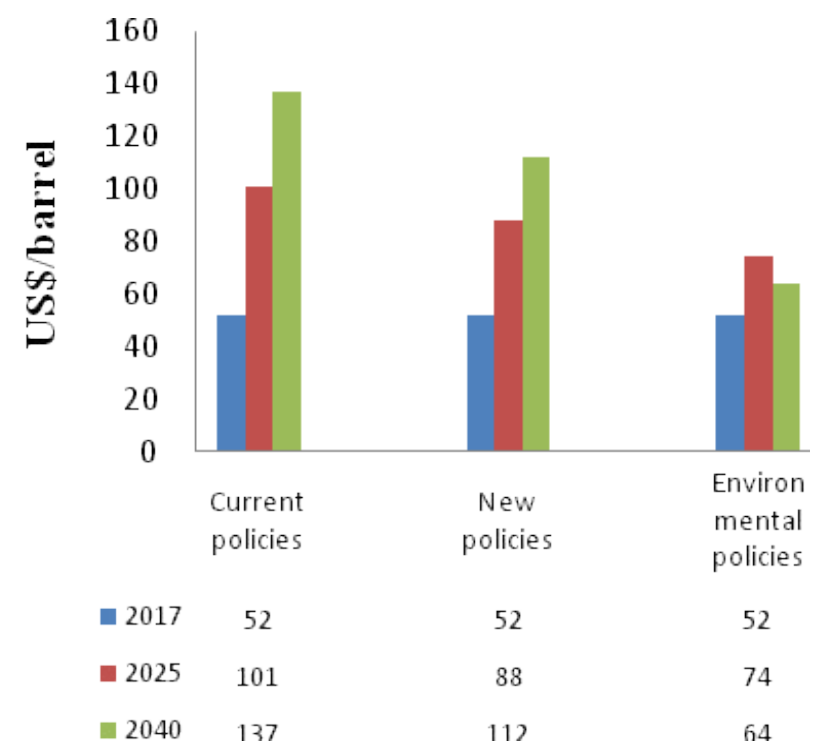

Figure 2: Oil price projection.

[5].

On the other side, this aeronautical influence is not only given by fuel uses, but also by noise contamination and high costs in the aircraft's operation and maintenance. In this way, the E-Fan $X^{5}$ [6] and Solar Impulse $2^{6}$ [7] programs are looking to decrease the combustion engine consequences through environmental benefits in the electric engine implementation [8].

Thus, similar to environmental and operational benefits, it is starting a manufacture and use electric engines market, not only in the aeronautic sector but also in the nautical, automobile and motorcycle areas, e.g. Tesla Model $\mathrm{S}^{7}$ [7], Formula $\mathrm{E}^{8}$ [9], Moto $\mathrm{E}^{9}[10]$ and Formula $1^{10}[11,12]$ with its hybrid engines.

Under these guidelines, some countries as Nor-

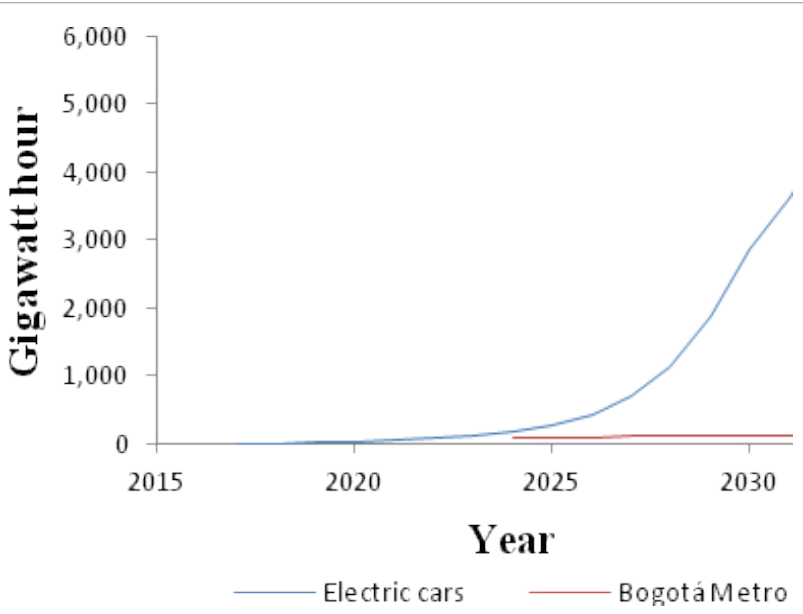

Figure 3: Electric energy demand projection for Colombia.

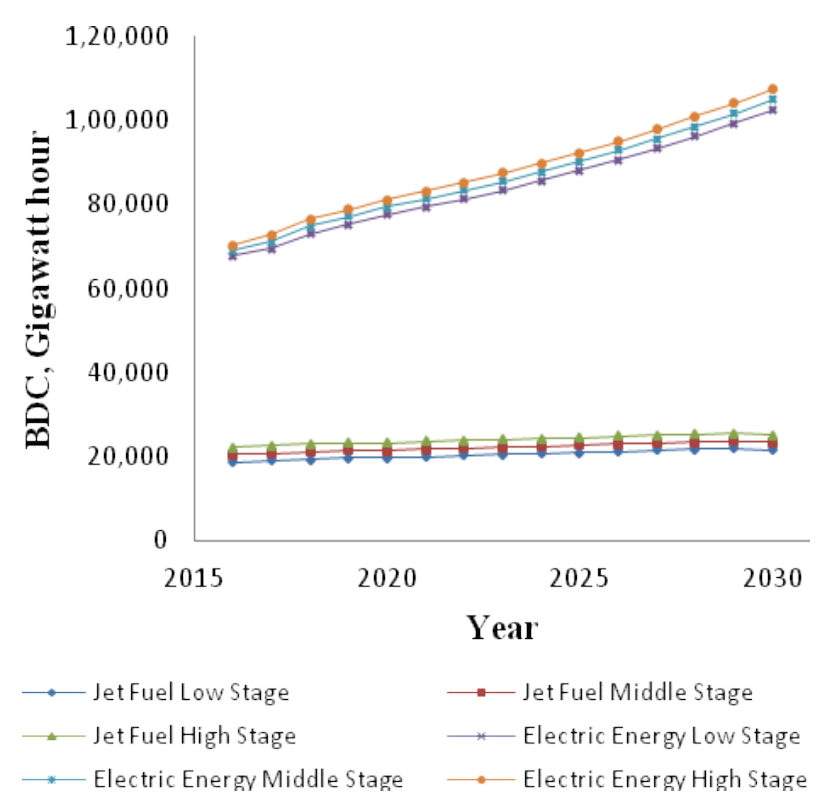

Figure 4: Total demand projection for Colombia.

way are aiming their policies in the electrification of their ground, aerial and nautical machines [13]. About aircraft, they have managed to reduce noise, operation costs, maintenance costs, maintenance times and environmental impact; without forgetting, high values reached on the performance, reliability, and safety $[14,15]$.

Although Colombia hasn't a clear traceability in the electric aviation development, it has got ahead in the use of electric transport with vehicles, buses, motorcycles, trolley cars, and metros (Medellín Metro and any months ago Bogotá Metro adjudication). Those successes have forced that the National Government implements actions about goods and services supported on the electric energy to improve and to get ready its infrastructure, 
national policies and adjudication methodologies to supply the future demand, Figure 3 and Figure $4^{11}[4,16,17]$.

In specific, ever since the electric engine has been a trend of public policies for a sustainable future, from the 2000 s began a predisposition in the engineering literature focused on electric aircraft, it is going from one paper per year to be more than 20 today [18]. Stoll, Bevirt, Moore, Fredericks, and Borer present a solution to the low power of electric engines. Due to the high flexibility in configurations, they propose a blown wing realized through the placement of several electric motors driving individual tractor propellers spaced along each wing. They realized to the increase the lift coefficients at take-off and landing flight conditions, and a decrease in the drag for a maximum range at cruise flight conditions [19].

On the other hand, Brooks and Salgueiro evaluate the acquisition, maintenance, operation and lifecycle costs of a small electrically-powered aircraft and a current piston-powered aircraft. This paper shows the electric engines direct and indirect benefits in small aircraft with short flight rang- es [20] Figure 5.

Continue with a multidisciplinary focus, German and Naru detect the electrically powered aircraft certification introductory with new and unique maintenance challenges. They present a paper supported in feedback from maintenance professionals who participated in interviews, and they discover concerns that may not be immediately apparent to engineers during the conceptual design phase [21].

Similarly, Bernabeo, Piancastelli, Malik, Al Azad, and Yaseen from the problems registered by combustion engines, show the electric aircraft benefits for the air instruction schools. The authors developed an experimental green trainer to validate the best configuration for this power pack and to findout critical issues on installation, safety, reliability and maintenance supported by a 300 hours flight program [8].

Unlike previous researches, Brelje and Martins make a general review of the state of art about electric, hybrid and turboelectric aircraft prototypes and concepts. Referencing the power and take-off range, the authors focus on the propulsion effects,

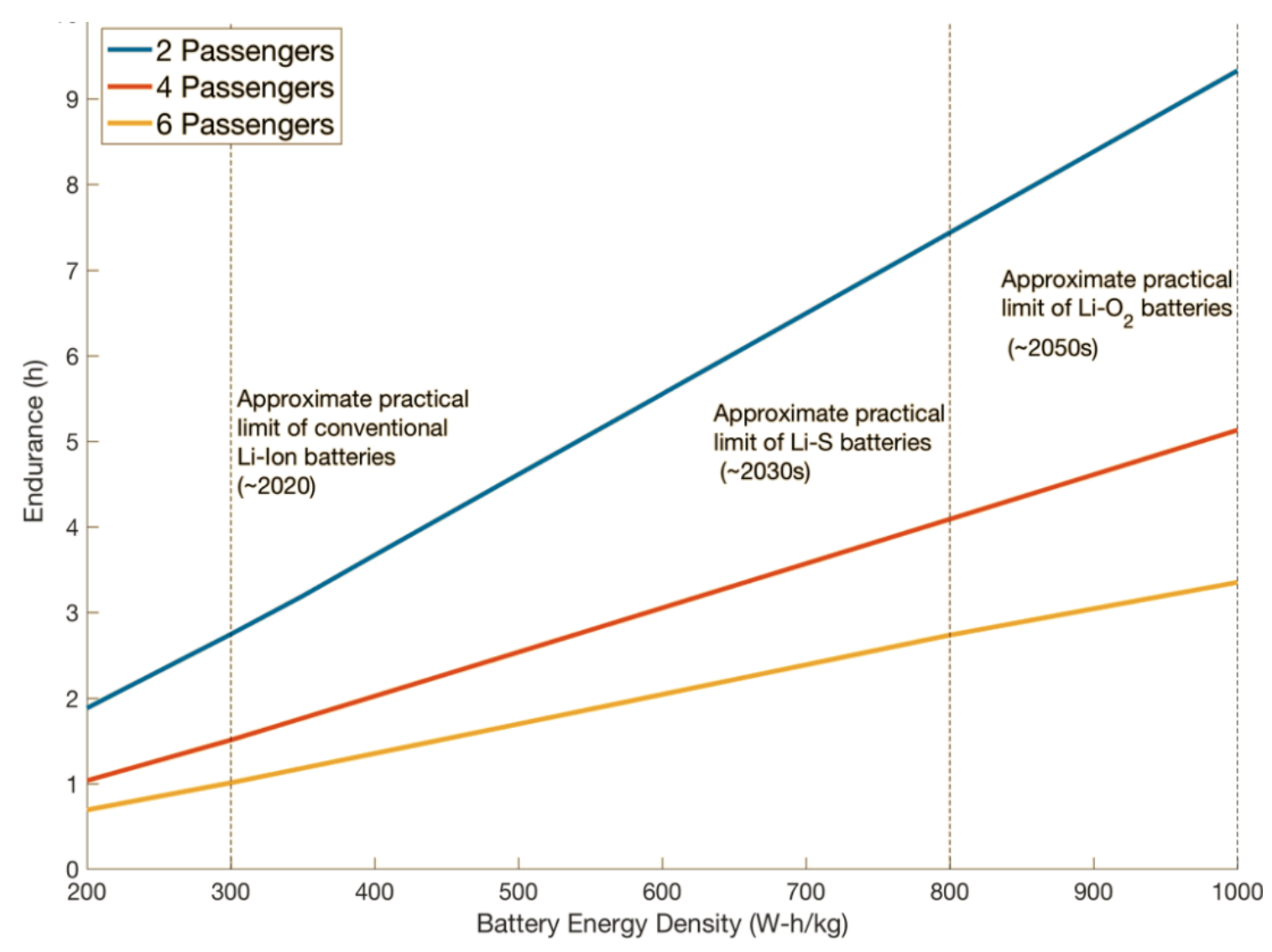

Figure 5: Endurance forecast assuming future battery technology (adapted from [20]). 
Table 1: State of art summary.

\begin{tabular}{|c|c|c|c|}
\hline Research team & $\begin{array}{l}\text { Publication } \\
\text { year }\end{array}$ & Tittle & Remarks \\
\hline $\begin{array}{l}\text { Stoll, Bevirt, } \\
\text { Moore, Fredericks } \\
\text { \& Borer [19] }\end{array}$ & 2014 & $\begin{array}{l}\text { Drag reduction through } \\
\text { distributed electric propulsion }\end{array}$ & $\begin{array}{l}\text { - Solution to the low power of electric } \\
\text { engines. } \\
\text { - Electric motors drive individual tractor } \\
\text { propellers spaced along of wing. } \\
\text { - Lift increased at take-off and landing; drag } \\
\text { decreased at cruise flight. }\end{array}$ \\
\hline $\begin{array}{l}\text { Brooks \& } \\
\text { Salgueiro [20] }\end{array}$ & 2017 & $\begin{array}{l}\text { Design Space Investigation } \\
\text { for a Small Electric General } \\
\text { Aviation Airplane }\end{array}$ & $\begin{array}{l}\text { - Evaluation between an electrically-powered } \\
\text { aircraft and a piston-powered aircraft. } \\
\text { - Evidence of electric engines benefits in } \\
\text { small aircraft with short flight ranges. }\end{array}$ \\
\hline $\begin{array}{l}\text { Naru \& German } \\
\text { [21] }\end{array}$ & 2018 & $\begin{array}{l}\text { Maintenance Considerations } \\
\text { for Electric Aircraft and } \\
\text { Feedback from Aircraft } \\
\text { Maintenance Technicians }\end{array}$ & $\begin{array}{l}\text { - Identification of new and unique } \\
\text { maintenance challenges in electric aircraft. }\end{array}$ \\
\hline $\begin{array}{l}\text { Bernabeo, } \\
\text { Piancastelli, } \\
\text { Malik, Al Azad \& } \\
\text { Yaseen [8] }\end{array}$ & 2018 & $\begin{array}{l}\text { Study and testing of a green } \\
\text { trainer to transform small } \\
\text { general aviation aircraft for } \\
\text { training into a no-emission } \\
\text { aerial vehicles }\end{array}$ & $\begin{array}{l}\text { - Evidence of electric aircraft benefits for the } \\
\text { air instruction schools. } \\
\text { - An experimental green trainer Development } \\
\text { by a } 300 \text { hours flight program. }\end{array}$ \\
\hline $\begin{array}{l}\text { Brelje \& Martins } \\
\text { [18] }\end{array}$ & 2019 & $\begin{array}{l}\text { Electric, hybrid and } \\
\text { turboelectric fixed-wing } \\
\text { aircraft: A review of } \\
\text { concepts, models, and design } \\
\text { approaches }\end{array}$ & $\begin{array}{l}\text { - General review of the state of art about } \\
\text { electric, hybrid and turboelectric aircraft } \\
\text { prototypes and concepts. } \\
\text { - Study prioritized on the engine's power, and } \\
\text { take-off range. } \\
\text { - Identification of future problems between } \\
\text { the aerodynamics and propulsion. }\end{array}$ \\
\hline
\end{tabular}

Table 2: Alpha Pipistrel lifecycle cost analysis.

\begin{tabular}{|c|c|c|}
\hline & $\begin{array}{l}\text { Internal } \\
\text { Combustion }\end{array}$ & Electric \\
\hline Engine & Rotax $91280 \mathrm{hp}$ & $\begin{array}{l}\text { Siemens Dynadyn } \\
60 \mathrm{~kW}\end{array}$ \\
\hline Aircraft list price & $\$ 103,000$ & $\$ 117,000$ \\
\hline $\begin{array}{l}\text { Time Before } \\
\text { Overhaul (TBO) }\end{array}$ & 1,500 hours & 2,500 hours \\
\hline Overhaul Cost & $\$ 13,000$ & $\$ 17,400$ \\
\hline Operating Cost & $\begin{array}{l}\$ 30,600 \text { (fuel } \\
\text { for } 1,500 \text { hours) }\end{array}$ & $\begin{array}{l}\$ 2,200 \\
\text { (electricity for } \\
2,000 \text { hours) }\end{array}$ \\
\hline $\begin{array}{l}\text { Total Cost } \\
\text { Between } \\
\text { Overhaul }\end{array}$ & $\$ 43,600$ & $\$ 19,600$ \\
\hline Normalized Cost & $\$ 55 /$ hour & $\$ 39 /$ hour \\
\hline
\end{tabular}

aerodynamic effects, sizing effects, weight effects, system safety effects, and noise and heat effects. They conclude with recommendations about the batteries, design problems, modeling, simulation, and multidisciplinary optimization which may only become apparent with high-fidelity physics-based analysis, including safety and economics [18] Table 1.

Therefore, Colombia cannot be opposed to the world advances and innovation challenges, even more, when it can get great benefits in aeronautical applications. For this goal, a two-seater electric training aircraft is the best option to get ahead in the uses of these electricity technologies, so at present, the batteries and electric motors can work by 90 minutes, which time is sufficient for an air training class (Figure 5) [22]. This could decrease the environmental impact and flight hour cost with a quick, simple, reliable and economic mainte- 
nance, Table 2; also, the engineering allows several aerodynamic and performance configurations to offer the best electric training aircraft in Colombia [23].

In the last years, Colombia has advanced on the manned and unmanned aircraft manufacturing with manufacture plants that have allowed, together with public and private programs as the PEDSAA, PEICA and Foro Plan Estratégico Aeronáutico 2018-2030 [24], the manufacturing of certified prototypes with a technological aeronautic pack designed, implemented and integrated under the triad: Academy-Industry-Government, such the Calima T-90 program by Colombian Air Force (FAC) and Corporation of the Colombian Aeronautical Industry (CIAC) [25].

These developments have reinforced the aeronautical infrastructure with national and international impacts, establishing opportunities and stimulating the technical, human, economic and intellectual skills. The incorporation of ACOPAER ${ }^{12}$ [13], $\mathrm{CIAC}^{13}$ [14], $\mathrm{FAC}^{14}$ [16], UAEAC ${ }^{15}$ [17], CAESCOL ${ }^{16}$ [18], MinDefensa ${ }^{17}$ [19], MinCiencias ${ }^{18}$ [20], MinComercio $^{19}$ [21], and other entities, gives the best scenario to take advantage of the experience, and thus, to use the national talent and knowledge to innovate in the manufacture of new aircraft prototypes with military and civil applications as a great market option.

Finally, the introduction section presents the electricity, energy and Jet Fuel demand reports graphs in Colombia. This information is completed with the analysis of the electric aircraft world market trends and the state of art to provide comments about the Colombian aeronautic sector development; the introduction section is reinforced with the research methodology section which presents the type of methodology used in the search, how was organized the information and its application in this paper.

Followed this, the configurations and design requirements section presents the engineers and pilots' demands to achieve manufacture an electric training aircraft, the authors will show all possible avionics, landing gear, tail, main wing, fuselage, and propulsion configurations to provide a preliminary design guidance. Also, the systems and subsystems required section presents all electric and electronic components necessary into the manufacture; this section will explain the energy storage system, electric propulsion system and electromechanical actuators with theirs possible uses and design architectures.

The sensitivity studies and preliminary estimates section complement these last sections. With a comparative study of baseline airplanes, the preliminary sizing is calculated, and under design demands and aeronautic bibliography the weight preliminary is calculated. By a QFD matrix, those sizing and weight calculations are evaluated, where the authors proposed some preliminary sketches.

Lastly, the services and capabilities required section presents the actions and recommendations that Colombia should do to achieve to get better its infrastructure, policies, and production plants, taking into its projections plans and its aeronautic public and private institutions. About these recommendations and the whole investigation, the authors registered in the conclusions section the most important info to help understand why this review research is important for national and global interests [23].

\section{Research Methodology}

This review article is the systematic review type, in which the authors used a rigorous process to identify, evaluate and synthesize all information about the manufacture of an electric training aircraft in Colombia with papers from 2010 until 2020 based on the global electric transport development. This was possible by query in databases, such IEEE Xplore Digital Library, Progress in Aerospace Sciences, Academy Google and Science and Air Power Journal; likewise, the news portals and Nation and International Programs Projections about the aeronautic and aerospace develop, and electric, energy and fuel consumption were queried.

On the whole, all that information of research articles, news and bibliography sources were evaluated and synthesized by a QFD Matrix to identify the customers' necessities focused on requirements, recommendations, design baseline aircraft and technical solutions based in the aeronautical bibliography to conclude which is the best choice of a Colombian electric training aircraft.

\section{Configurations and Design Requirements}

The significance of aviation training is focused on acquiring skills to overcome adversities safely while 
operating functions are developed. This requires constant feedback and catching up on aspects that intervene in the pilot behavior with respect to his assigned aircraft. Consequently, it is correct to declare that air training schools must assume to be technologically competent institutions that accept training challenges, concerning their interests.

To provide a high-quality product, focused on the needs of instructors and students, a versatile and economical aircraft in its operation must be projected. These requirements are focused on looking for efficiency and balance from design, solving aspects such:

- Response feeling in primary controls.

- Flight ergonomics.

- Good maneuverability, with a design and performance that allows good feelings in training exercises at maximum admissible speed and stall speed.

- Longitudinal and lateral-directional flight stability at maximum admissible speed and stall speed.

- Excellent visibility between the student pilot and instructor pilot, similarly, exterior and interior of the cockpit.

- Structural design suitable to support the instruction maneuvers load factor, and hard landings, preventing critical scenarios.

- Simple flight controls with an avionics to allow the student pilot to develop their flight skills, and he can make an optimal transition to new aircraft with greater technology, speed, and wingspan.

- Fast and agile engine response to allow fly at high altitudes, with enough range to meet air instruction requirements.

- Fast, simple and economic maintenance.

Thus, as an aspect to consider, the proposed aircraft should meet a minimum of requirements to carry out its task most appropriately and safely in the primary phase of air instruction. Where the composite material and light metals uses should be motivated with design, manufacture and installation benefits and challenges concerning the machines, tools, and training. In this proposal, the communication, navigation, and lightning safety system installation method must be taken into ac- count due to the challenges that these electronic and electric systems impose in the use of composite materials and light metals with direct impacts on the cost, duration of production, ease of manufacturing and aircraft life.

\section{Avionics considerations}

It is convenient to present a reliable last generation avionics that meets training flight necessitates with a simultaneous double-command controls and an instrument panel simple but complete in its subsystems, such: $\mathrm{PFD}^{20} / \mathrm{MFD}^{21}$ digital displays, audio panels, transponder, GPS ${ }^{22}$, engine controller panels, primary/secondary controls controller panels, and $\mathrm{VHF}^{23}$ communication and navigation systems. These components are important together with an analog redundant safety system, and the flight simulators development.

\section{Landing gear considerations}

Another important feature is the balance between aerodynamic and structural design, it must be focused on the types of maneuvers to generate the most efficient aerodynamics that allow stability at stall speed and maximum permissible speed. Likewise, the landing gear should offer comfortable and ergonomics feelings, for that the tricycle alternative (Figure 6) is the best option to allow hard landings and easy take-offs with a good primary controls response by an elevator, aileron, and rudder. It should study the high-lift device implementation case if required (flap, slat or slot) [26].

\section{Fuselage considerations}

The fuselage must support the maneuver loads, and the weight of the crew and the main systems, it provide longitudinal and lateral stability without decreases the flight performance. Thus under direct customers, users, and investors requirements, the "Side-By-Side" seat alternative (Figure 7) is postulated as the best configuration to allow an ideal contact between the instructor pilot and student pilot. The door alternative could be the cabin or cockpit type (Figure 7), which together with pressure system as a pressurized cabin, pressurized hose o under-pressurized cabin; it would improve the pilot's skills, being recommended the pressurized hose by the system weight. The primary influences of the fuselage configuration will be imposed on the cost of flight operation, cost of aircraft production, performance, duration of production, 


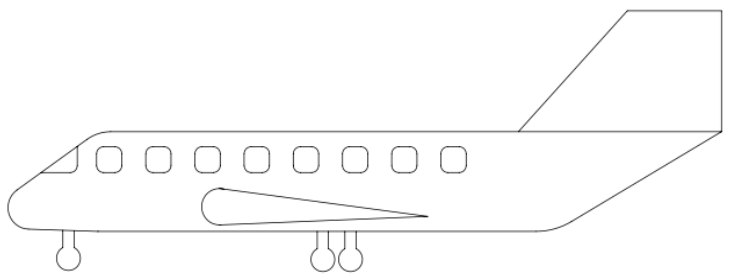

1. Multi-gear

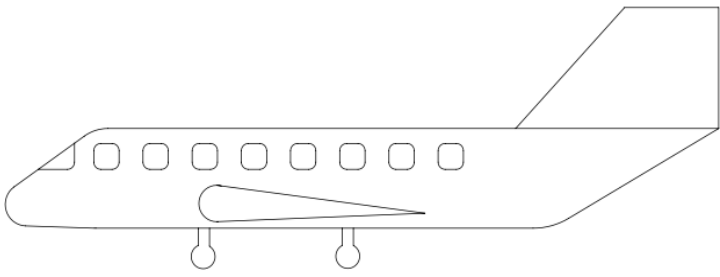

3. Bicycle

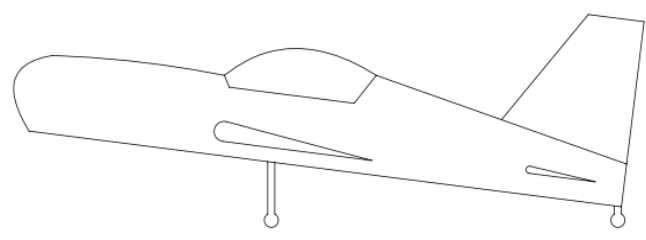

2. Tail gear

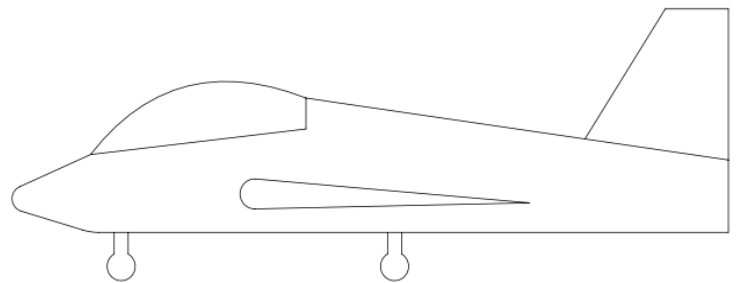

4. Tricycle

Figure 6: Landing gear configurations alternatives.

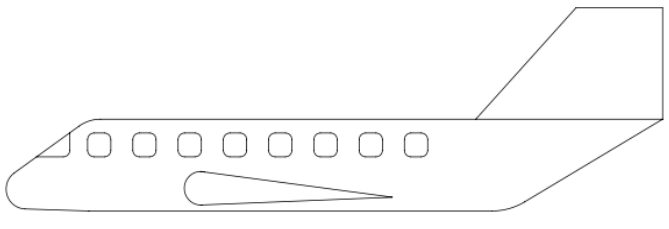

1. Cabin

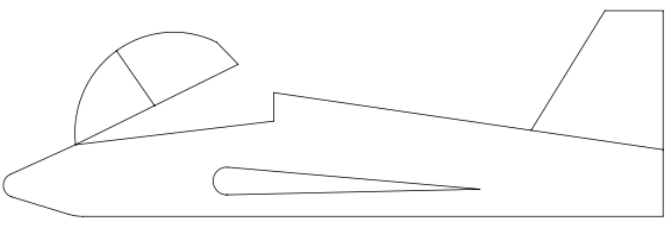

2. Cockpit
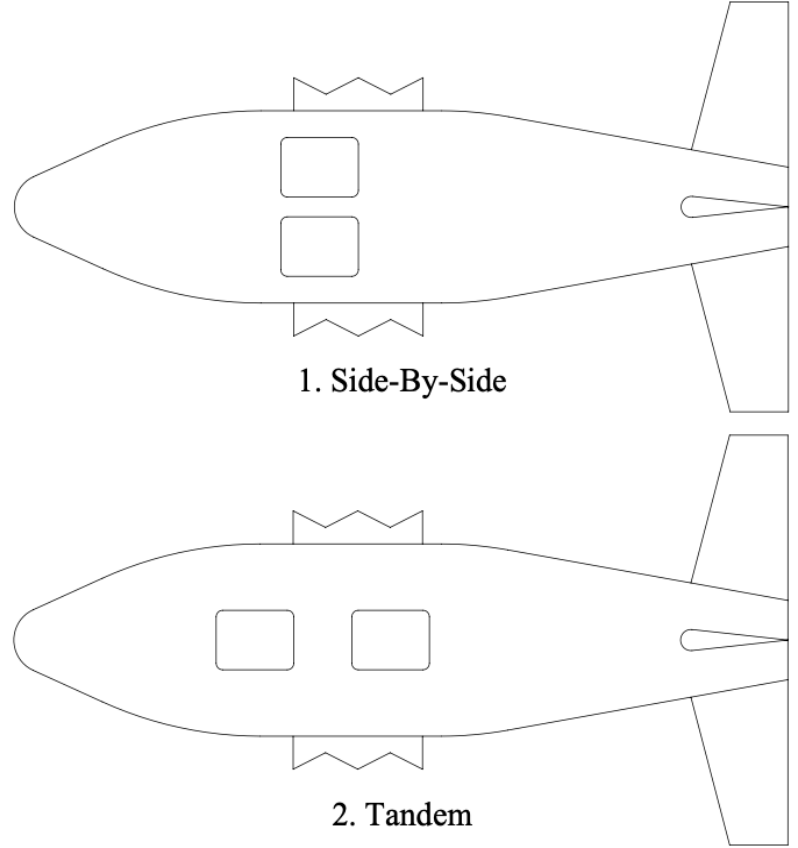

Figure 7: Fuselage configurations alternatives.

ease of manufacturing, crew comfort and aircraft life [26].

\section{Main wing consideration}

Complementing the fuselage, the main wing, in addition to generating lift, it should be the primary lateral stability and performance source. Thinking about safety requirements, cost, duration of production, ease of manufacturing, maneuverability and aircraft life, the next configuration parameters should be considered, such: Number of wings, wing location, wing type, high-lift device, sweep configu- ration, shape, structural configuration, airfoil, incidence angle and dihedral angle [26].

For an electric training aircraft, a monoplane high wing type or monoplane low wing type should be evaluated Figure 8. The high wing would be a stable option, but with late response trends in controls; instead, the low wing would be a maneuverable option, but with unstable trends in flight [27]. This could be improved by a fly-by-wire power transmission in primary/secondary controls, highlift device, and a rectangular or mixed wing (tapered and rectangular wing). A fixed-wing sweep 


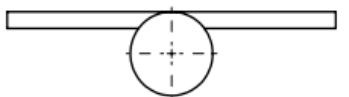

1. High wing

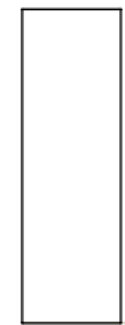

1. Rectangular

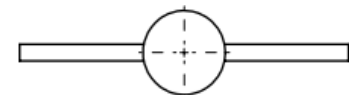

2. Mid-wing

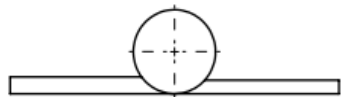

3. Low wing

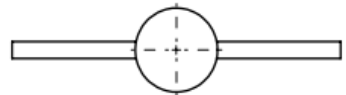

1. Monoplane

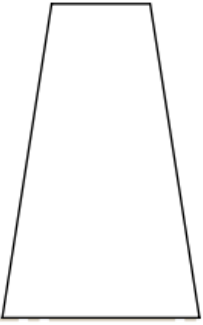

2. Tapered

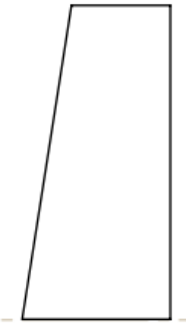

3. Swept back

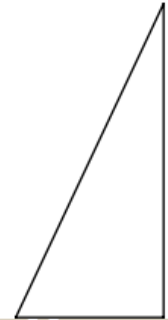

4. Delta

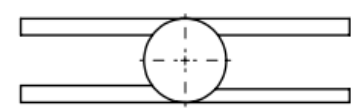

2. Biplane

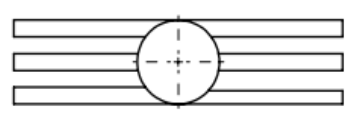

3. Tri-plane

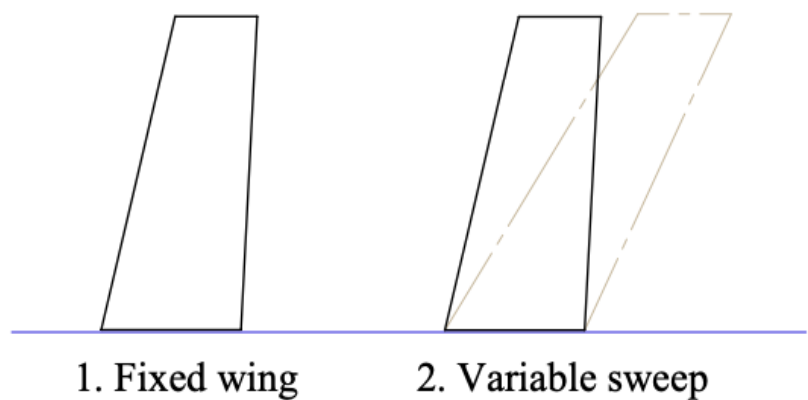

Figure 8: Main wing configuration alternatives.

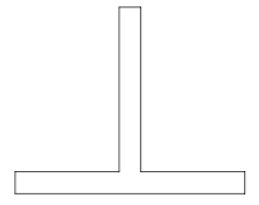

1. Conventional

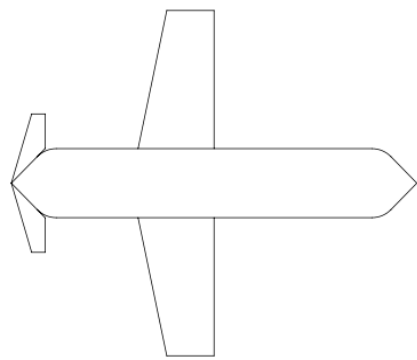

1. Aft tail

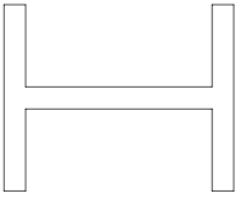

2. H-tail

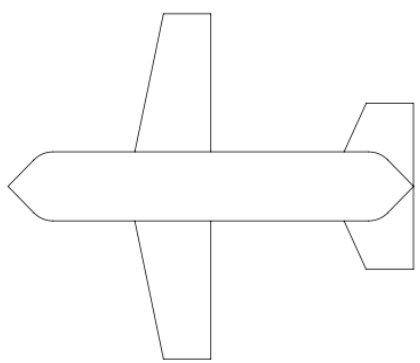

2. Canard

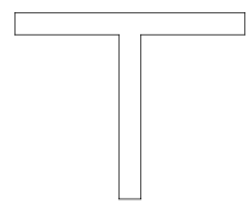

3. T-tail

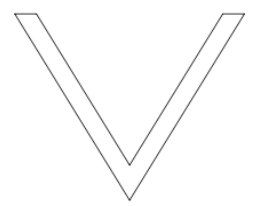

4. V-tail

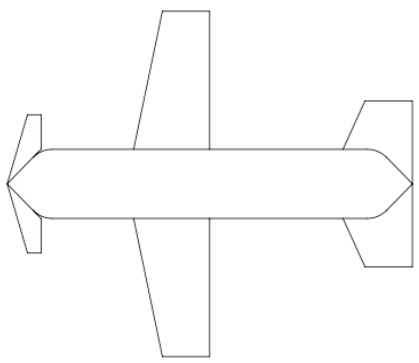

3. Three surfaces

Figure 9: Tail configurations alternatives.

and the dihedral angle will allow stable and maneuverable flight conditions with a full airfoil analysis (Figure 8). Thus, under flight requirements by customers, users and investors, a reliable structural, aerodynamic and stability studies must be carried out to choose the best option that provides a balance in the aircraft efficiency. It's recommended a thorough analysis with CFD tools in this process.

\section{Tail considerations}


As a complement to the main wing, the tail configuration must be aimed at ensuring longitudinal and lateral-directional stability and maneuverability, allowing control and balance. The tail location, horizontal and vertical tail type and attachment method will be factors to take in account, Figure 9 [26]. An important consideration must be made, the wing-Fuselage-Tail combination generates physical phenomena that will affect aircraft performance $[27,28]$; optimal design, and strict evaluation will be the maneuverability and stability secret at aircraft detailed design [29].

For an electric training aircraft, the conventional and T-tail configuration should be evaluated, without forgetting the $\mathrm{V}$-tail configuration and its possible performance, Figure 9 . The main reason to choose any configuration will be engine location, pitch moment and longitudinal gravity center location $[26,28]$, allowing aft a conventional tail, a canard or three surfaces configuration (Figure 9) with the fixed tail, moving tail or adjustable attachment alternatives. The best way to know how to choose it will be software tools as $\mathrm{AVL}^{24}$ [30] or $A A A^{25}$ [31], under flight requirements by customers, users, and investors. Thus, in the preliminary design phase is taking into account the conventional tail configuration, but in future studies could choose other configuration options, such: V-tail, T-tail, $\mathrm{H}$-tail or inverted U.

\section{Propulsion system considerations}

Finally, on the electric aircraft flight, continuous and dynamic flight cycles will be possible where the electric motor would never be in the "Break- $\ln ^{26 "}$ status [18,32-34]. It will allow high altitudes flights without supercharger or turbocharger systems, and the energy charging at low periods [8,33-35]. The good evaluation of the propeller type configuration (pusher or tractor), number of engines, engine location and the thrust line generated would ensure optimum levels of control, maneuvering, stability, flight time and performance [36,37]; the cockpit, engine and batteries cooling system will allow high operating margins, without decrease pilots and aircraft attitude and aptitude [18,26,33,34].

For an electric training aircraft, its propulsion system will be by an electric motor powered by Siemens or Rolls-Royce PLC [34], they are the most important industrial technology companies in the manufacture of electric engines. The configuration alternatives evaluation will be focused on the tractor propeller type with the single-engine in front of the nose, but in future studies, it could choose small multi-engines with a pusher or tractor propeller type inside fuselage mid-section, inside the wing, top of the wing, under wing, inside the verti-

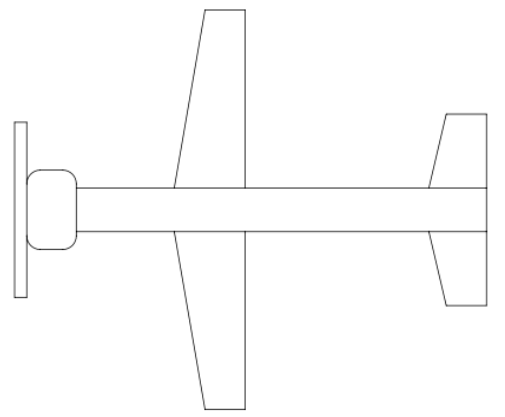

1.Tractor (single-engine) Pro-driven

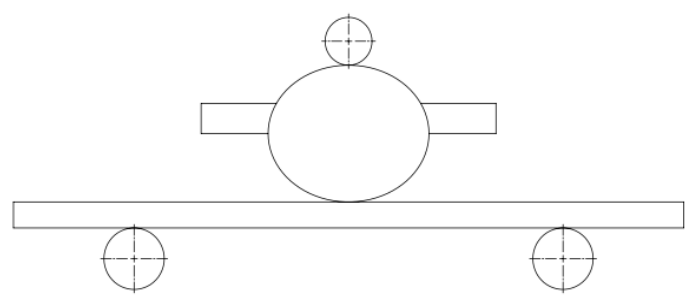

1. Tri-engine

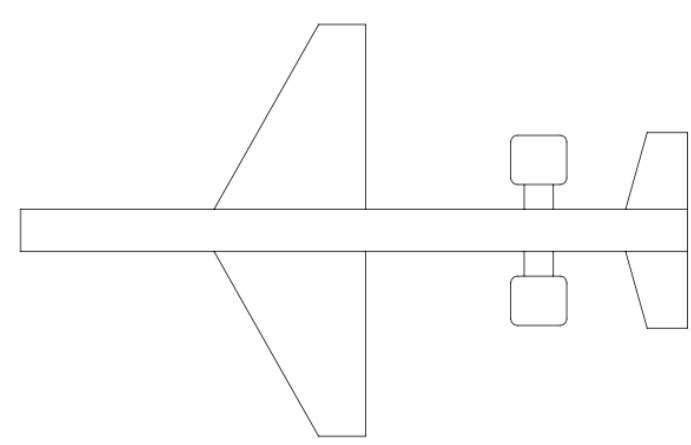

2. Pusher (twin-engine)

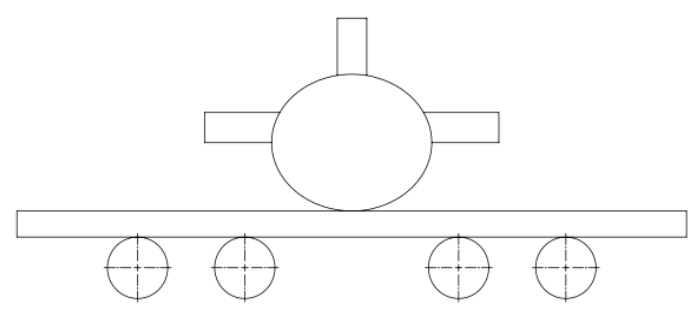

2. Four-engine (under wing)

Figure 10: Engine configuration alternatives. 
cal tail, side of the fuselage at aft section, or top of the fuselage, Figure $10[19,34]$. The propulsion system features will depend on the cost of flight operation, cost of aircraft production, performance, duration of production, ease manufacturing, maneuverability, aircraft life and the systems and subsystems weight.

\section{Systems and Subsystems Required}

Rosero, Ortega, Aldabas \& Romeral (2007, p.3) claim that "In a conventional architecture (Figure 11 is a basic schematic) fuel is converted into power by the engines. Most of this power is used as propulsive power to move the aircraft. The remainder is converted into four main forms of non-propulsive power: Pneumatic power, mechanical power, hydraulic power and electrical power". But until this day, a new aircraft alternative has emerged to replace it, it known as MEA $^{27}$ (Figure 12). Similarly, Rosero, Ortega, Aldabas \& Romeral
(2007, p.3) claim that "Nowadays, novel ways of generating, distributing, and using power onboard are examined at aircraft level. Hybrid or bleed-less air conditioning systems, $\mathrm{MEEs}^{28}$, fuel cells, variable frequency generators, complex embedded digital systems and distributed systems architectures are just a few of the technologies vying for space on forthcoming aircraft; the concept is known as MEA as presented in Figure 12" $[15,22,38,39]$. Where, electrical systems can be used up to in the actuation system, wing ice protection system and environmental control system $[15,22,39,40]$.

\section{General considerations}

The $\mathrm{EMAs}^{29}$ could be the ideal option to decrease the weight, maintenance, and production costs, these new components would require highly reliable, safe, fault-tolerant, autonomously controlled electrical power systems to deliver higher quality power and electrical levels to the aircraft's

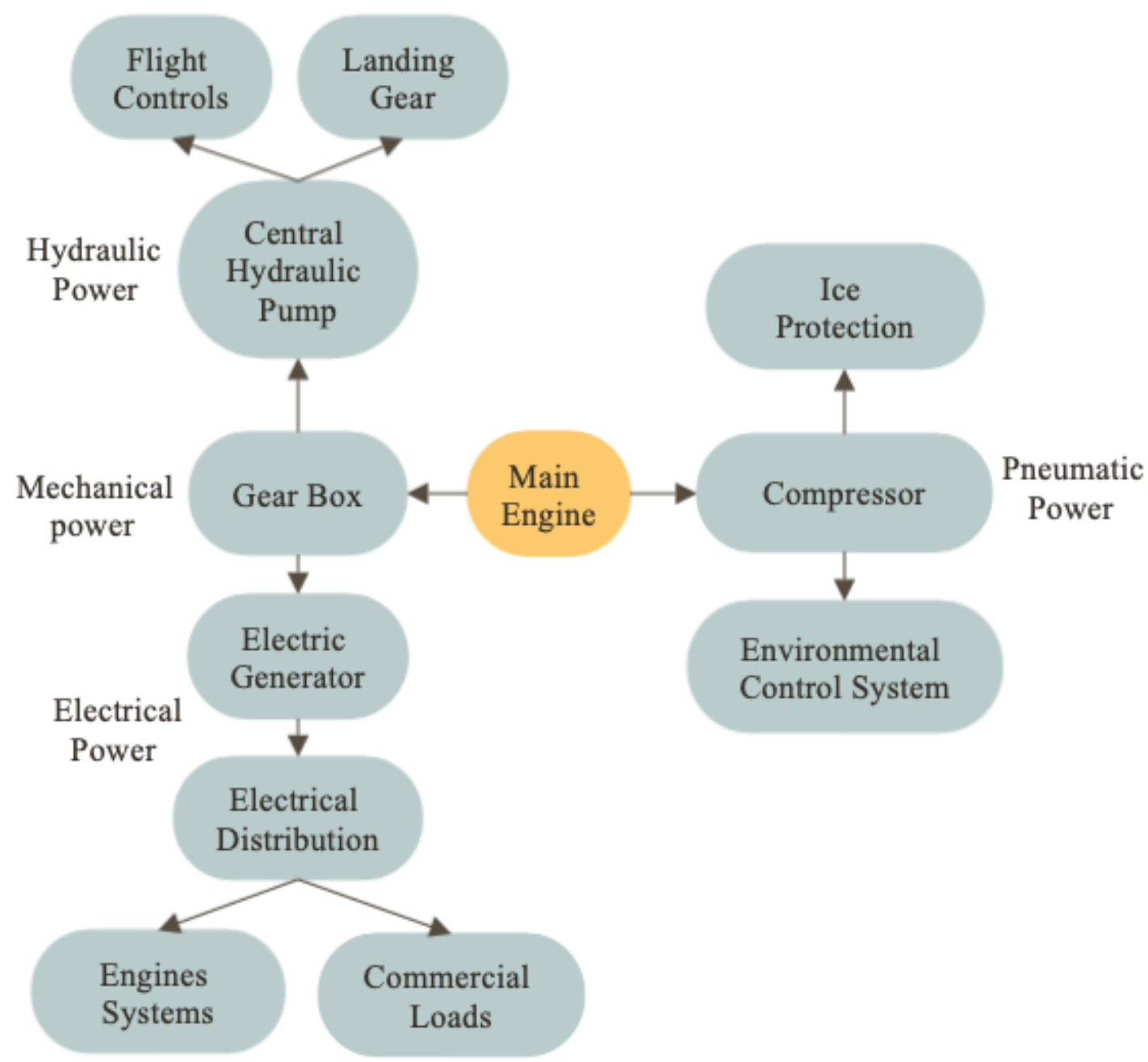

Figure 11: Schematic of conventional power distribution (adapted from [15]). 


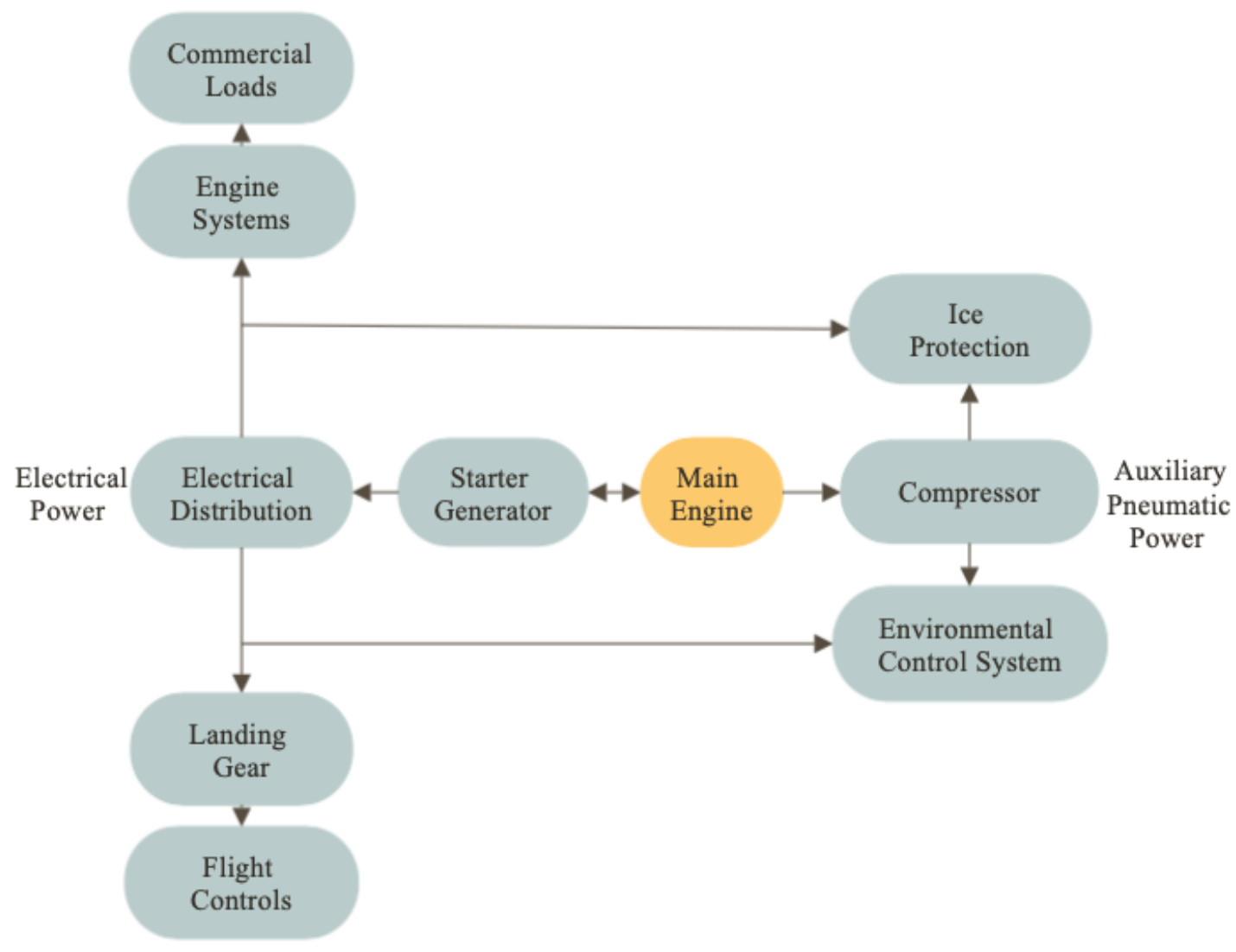

Figure 12: Schematic of MEA Power Distribution (adapted from [15]).

loads $[15,22,34,39]$.

Considering the Figure 12 , the main engine, (exclusively electric) converts $A C^{30}$ [31] or $\mathrm{DC}^{31}$ [32] current to mechanical propeller shaft power with properties, such $[23,34]$ :

- Speed is proportional to output power per unit volume.

- Large motors have a higher specific torque and are therefore more efficient than small one.

- Motor efficiency improves with speed.

- A motor can be modified for any voltage.

- Most motors can stay overloaded for short periods without being damaged.

- The output from any given motor us constrained by the cooling arrangement.

- Motors with similar cooling system have a rated torque almost proportional to the rotor volume (roughly the overall motor volume).

1. Front battery.

2. Coupling box.
3. Electric motor.

4. Propeller coupling.

5. Cooler system.

6. Fuse box.

7. Motor controller.

\section{Electrical energy storage systems consider- ations}

The EESS ${ }^{32}$ is used as support depending on the electrical architecture and energy management and it's complementary in term of safe (dis)charge rate, specific energy ${ }^{33}$ [18] and specific power ${ }^{34}$ performance [18]; it contributes also to control the electrical network and to ensure its reliable operation with aeronautical applications, such: Ultra-capacitor, fuel cell, super-capacitors, and Lithium-ion Polymer Batteries. These options are environmental cleaner, quieter, light and easy to fix or replace with refuel times of up to five minutes to one hour $[20,41,42]$.

The aircraft battery will store electrical energy and will provide energy to start the engine; it should store a limited supply of back-up power if 
the alternator system or generator system fails. A key assumption in a future model is the packing of all batteries in the nose compartment of the aircraft, because of stability (static margin) constraints [28]. Another way will be getting to pack in the wings, it would most likely result in higher aircraft endurance since this would improve the energy available while not make making the aircraft nose-heavy [20].

\section{Electric propulsion system considerations}

Conceptually, the electrical power would be produced by starter/generator of the main engine; the power is transferred out of the engine through wires that feed into a fault-tolerant electrical network to drive the aircraft subsystems. Electronic power converters would transform the electrical power and gearboxes would be necessary $[15,38,40]$.

When the total thrust is produced by an electric motor an electrical architecture choices (Figure 13 and Figure 14) will be strongly coupled with performance, weight, and flight safety. For the electric training aircraft proposed, the electric propulsion system should include the following

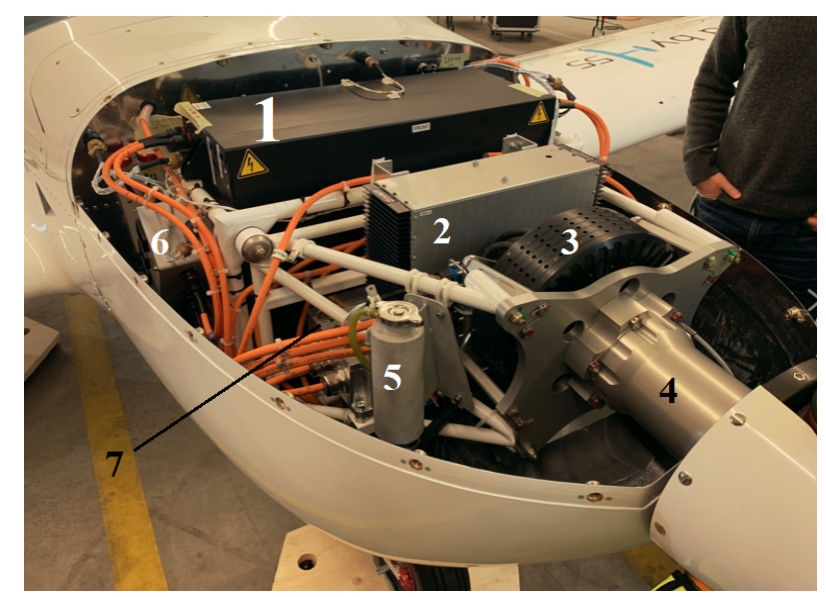

Figure 13: Electric propulsion system [50].
$[18,22,34,38,40]:$

- Energy storage: A battery (or alternative technology such as ultra-capacitor or fuel cell) designed for high (dis)charge rate, safety, specific energy and specific power.

- Generator: Converts mechanical shaft power into AC electrical power.

- Rectifier: Converts AC power to DC electrical power.

- Motor: Converts AC or DC current to mechanical shaft power.

- Inverter: Converts DC electrical power to AC power. It can be used as a variable-frequency drive for $\mathrm{AC}$ motors.

- Bus: An electrical conductor that transfers electrical power from source to destination.

- Motor controller: Closely related to inverters, motor controller use DC power to generate time-varying currents in the armature coils of brushless DC and switched-reluctance machines. Motor controllers respond to position or speed feedback from the motor and do not necessarily generate sinusoidal currents.

- Fault current limiter: Prevents large currents during short-circuit events (essentially a circuit breaker). For DC superconducting applications, superconducting fault current limiters (SFCLs) are used, which operate on different physical principles.

In addition to the previous information, the generator power control units, inverters, converters, and motor controllers should include IGBTs ${ }^{35}$ to improve the vibration resistance, electromagnetic compatibility, and size constraints [15,38-40].

In aeronautic applications, there are some challenging operating conditions for electric motors and their systems with areas where improvements

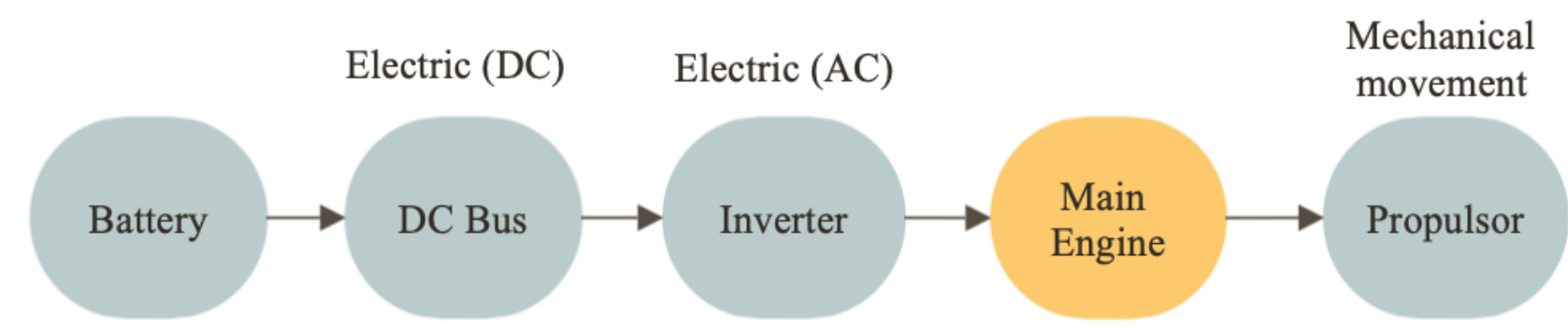

Figure 14: Electric propulsion systems for an electric aircraft. 
must be made in terms of the weight, volume, cost, and reliability. Thus, the electric motors, generators, converters, and wires dominate the aircraft weight and an optimal engine location, number of engines, generators and an effective cooling system must be estimated; with these considerations, assuming a past of heavy electric engines, three times lighter superconducting engines have been developed in recent years compared to turbine engines in terms of power density [18,38-40].

\section{Electromechanical actuators considerations}

Unlike conventional aircraft, to reduce weight and eliminate any system that decreases the flight efficiency, it is suitable to get replace the systems that depend on mechanical, hydraulic and pneumatic sources. The trend to move towards "all-electric" aircraft means that all power off-takes from the aircraft are electrical, resulting in fully-operative electrical power actuators and a mastery of electric flight control architecture $[15,39,40]$.

In these systems, the electro-hydrostatic, hybrid and electromechanical actuation for primary and secondary flight controls (as well as new landing gear, braking, nacelle actuation, and vertical/horizontal stabilizer architectures [22,43]) should be examined. In these systems, an electric motor di- rectly drives a pump, a fan, or an actuator with the disposition to drive the position, speed, torque and flow, together with monitoring and communication systems, Figure 15 [15,39,40].

These electromechanical systems should be within a decentralized and redundant system, while maintaining high levels of safety. These highly safe and reliable technologies would be jamming free and will help the social demand for a sustainable transport that ensures continuity in operation even in the case of a fault, making automatic checking for faulty signals easier which allows damage channels to be identified before they can jeopardize the safety whole aircraft. This dual power redundant electronic system should provide a motor drive, speed closed-loop, and control management helping to predict how long an actuator will last, introducing the predictive maintenance instead of preventive maintenance increasing the margin of safety $[15,22,39,40]$.

In this way, these digital systems are more reliable, lighter and more adaptable to change or modifications, as well as providing self-test capability. Consequently, under recommendations and flight requirements by customers, users and investors, it should have not physical connections between sensors, controls, and actuators; where the aircraft

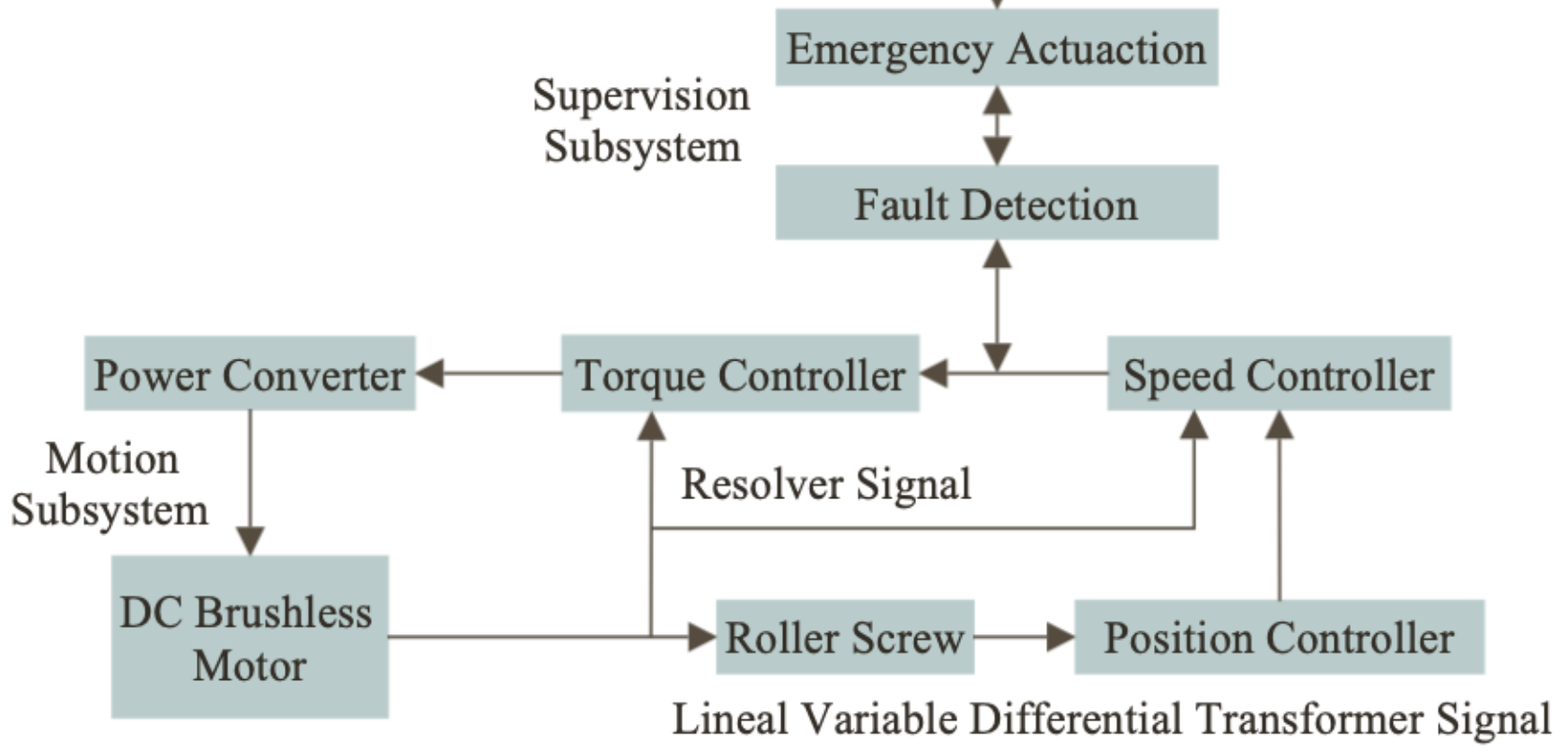

Communication Bus

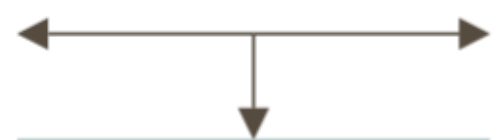

Fault Detection

Figure 15: Direct drive architecture for electro-mechanic actuators. 
will fly by the Fly-By-Wire system on the primary controls exclusively, and secondary controls if required, with at least half of the total communication bandwidth. Fortunately, new protocols of redundant systems are being validated and verified establishing standards for future, particularly for Fly-by-wire system $[15,39,40]$.

\section{Sensitivity Studies and Preliminary Esti- mates}

After a preliminary estimate of design, systems and subsystems requirements for the flight operation of an electric training aircraft, it is mandatory to conduct sensitivity studies on the parameters, such:

Payload, $W_{P L}$

Empty weight, $W_{E}$

Range. $R$

Endurance, $E$

Lift-to-drag ratio, $L / D$

Specific fuel consumption, $C_{P}$ or $C_{j}$

Propeller efficiency, $W_{P L}$

The reason for doing this is to find out which parameters will drive the preliminary design, determining the areas of technological change must be proposed. Similarly, it helps to find if some new mission capability must be achieved, from optimistically or pessimistically consideration, to provide a quick estimate impact on the design.

\section{Preliminary sizing}

To define the preliminary sizing and to carry out the sensitivity study, the mission parameters specifications will be about range requirements, cruise speed and payload.

This sensitivity study is applied to an aircraft propelled by single-engine propellers with the FAR
23 certification base [44]:

Determination of the mission payload weight, $W_{P L}$ :

$W_{P L}=0 \mathrm{lb}$

Estimate of a likely value of takeoff weight, $W_{\text {TO }}$ :

$W_{\text {TO }}=1568.5 \mathrm{lb}$

This value is obtained by comparing the mission average takeoff weight of the FAR 23 type conventional and electric airplanes, where electric airplanes are the main airplanes compared [44].

Determination of the mission fuel weight, $W_{F}$ :

1. Engine start and Warm-Up.

2. Taxi.

3. Takeoff.

4. Climb and accelerate.

5. Cruise.

6. Loiter.

7. Descent.

8. Landing, Taxi and Shutdown.

To understand the determination of mission fuel weight, the fuel-fraction is defined as the ratio of end weight to begin weight, assigning a numerical value to the fuel-faction corresponding to each phase, Figure 16 and Table 2 [44].

Phase 1: Engine start and warm-up

$\frac{W_{1}}{W_{T 0}}=0.995$

Phase 2: Taxi

$\frac{W_{2}}{W_{1}}=0.997$

Phase 3: Takeoff

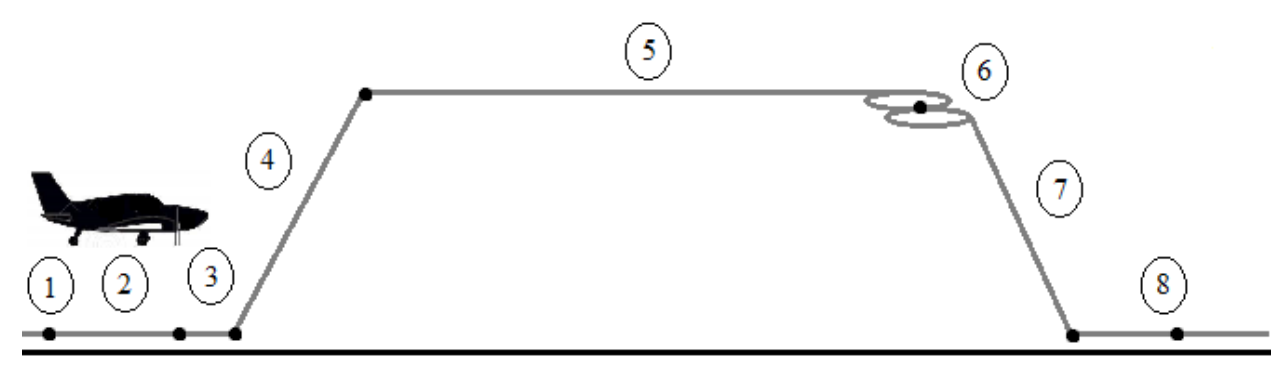

Figure 16: Mission profile for an arbitrary airplane. 
Table 3: Suggested fuel-fractions for several mission phases.

\begin{tabular}{|l|l|l|l|l|l|l|}
\hline & $\begin{array}{l}\text { Engine start, } \\
\text { Warm-up }\end{array}$ & Taxi & Takeoff & Climb & Descent & $\begin{array}{l}\text { Landing, Taxi, } \\
\text { Shutdown }\end{array}$ \\
\hline Mission phase & 1 & 2 & 3 & 4 & 7 & 8 \\
\hline Single engine airplane & 0.995 & 0.997 & 0.998 & 0.992 & 0.993 & 0.993 \\
\hline
\end{tabular}

$\frac{W_{3}}{W_{2}}=0.998$

Phase 4: Climb to cruise altitude and accelerate to cruise speed

$\frac{W_{4}}{W_{3}}=0.992$

\section{Phase 5: Cruise}

Taking into account the Table 3 information, in a flight range of 276.19 statute miles, which is the flight distance traveled in 90 minutes (average training flight class time [20]) at cruise speed in 160 knots, it obtains:

$$
\begin{aligned}
& R_{c r}=375\left(\frac{n_{p}}{c_{p}}\right)_{c r}\left(\frac{L}{D}\right)_{c r} \operatorname{Ln}\left(\frac{W_{4}}{W_{5}}\right) 36[44] \\
& \frac{W_{5}}{W_{4}}=0.941
\end{aligned}
$$

\section{Phase 6: Loiter}

In this flight phase it is assumed that the mission is a straight flight, without interruptions in the cruise phase, similarly, in runway approach circuits. Therefore, loiter flight phase will be:

$$
\frac{W_{6}}{W_{5}}=1
$$

\section{Phase 7: Descent}

$$
\frac{W_{7}}{W_{6}}=0.993
$$

Phase 8: Landing, taxi and shutdown

$$
\frac{W_{8}}{W_{7}}=0.993
$$

It is now possible to calculate the mission fuel-fraction, $M_{f f}$ from:

$$
\begin{aligned}
& M_{f f}=\left(\frac{W_{1}}{W_{T 0}}\right) \prod_{i=1}^{i=7}\left(\frac{W_{i+1}}{W_{i}}\right) \\
& M_{f f}=0.9111
\end{aligned}
$$

Table 4: Suggested values for $L / D, C_{j}, \eta_{P}, C_{P}$ and for several mission phases.

\begin{tabular}{|l|l|l|l|}
\hline & $L / D$ & $C_{P}$ & $\eta_{P}$ \\
\hline Single engine airplane & $8-10$ & $0.5-0.7$ & 0.8 \\
\hline
\end{tabular}

Thus, the value for the mission fuel weight can finally be determined, assuming the mission reserve fuel-fraction is 0.25 , being the $25 \%$ of $W_{F_{\text {usado }}}$

$$
\begin{aligned}
& W_{F}=W_{F_{\text {usado }}}+W_{F_{\text {reserva }}} \\
& M_{F_{\text {usado }}}=\left(1-M_{f f}\right) W_{T 0} \\
& W_{F}=\left(1-M_{f f}\right) W_{T 0}+W_{F_{\text {reserva }}} \\
& W_{F}=174.27 \mathrm{lb}
\end{aligned}
$$

Calculation of a tentative value for $W_{O E}$ :

$$
\begin{aligned}
& W_{O E_{\text {tent }}}=W_{T o_{\text {guess }}}-W_{F}-W_{P L} \\
& W_{O E_{\text {tent }}}=1394.23 \mathrm{lb}
\end{aligned}
$$

Calculation of tentative value for $W_{E}$ from:

The weight of all trapped (unusable) fuel and oil $W_{t f o}$ is assumed as $0.5 \%$ of $W_{T O}$. On the other hand, the estimated weight of the crew $W_{\text {crew }}$ is $400 \mathrm{lb}$. (instructor pilot and student pilot), considering future military applications within the flight mission specification [44].

$$
\begin{aligned}
& W_{E_{\text {tent }}}=W_{O E_{\text {tent }}}-W_{t f o}-W_{\text {crew }} \\
& W_{E_{\text {tent }}}=986.39 \mathrm{lb}
\end{aligned}
$$

Determination of the allowable value of empty weight, $W_{E}$ :

With the numerical values for quantities $A$ and B, listed in Table 4, it could obtain:

$$
\begin{aligned}
& W_{E}=10 \frac{\log _{10} W_{T O}-A}{B} \\
& W_{E}=981.37 \mathrm{lb}
\end{aligned}
$$

Comparison between $W_{E_{\text {tent }}}$ and $W_{E}$ :

In this step, a tolerance between $W_{E_{\text {tent }}}$ and $W_{E}$ of $0.5 \%$ is usually sufficient at this stage in the design process. 
Table 5: Regression line constants A and B.

\begin{tabular}{|l|l|l|}
\hline Airplane Type & A & B \\
\hline Single engine propeller driven & -0.1440 & 1.1162 \\
\hline
\end{tabular}

Table 6: Preliminary data.

\begin{tabular}{|l|l|}
\hline Reserve fuel fraction $\left(M_{\text {res }}\right)$ & 0.25 \\
\hline Mission fuel-fraction $($ ff $)$ & 0.9111 \\
\hline $\begin{array}{l}\text { Trapped (unusable) fuel and oil fraction } \\
\left(M_{t f o}\right)\end{array}$ & 0.005 \\
\hline Payload Weight $\left(W_{P L}\right)$ & 0 lbs. \\
\hline Crew weight $\left(W_{\text {crew }}\right)$ & 400 lbs. \\
\hline
\end{tabular}

$$
W_{E_{t o l}}=\frac{(986,39 l b-981,37 l b)(100)}{981,37 l b}=0,51 \%
$$

\section{Sensitivity studies}

Done the preliminary sizing calculations the Table 5 has been obtained allowing determine the sensitivity study for the electric training aircraft proposed [44].

$$
\begin{aligned}
& C=\left(1-\left(1+M_{r e s}\right)\left(1-M_{f f}\right)-M_{t f 0}\right) \\
& C=0.884 \\
& D=W_{P L}+W_{c r e w} \\
& D=400 \mathrm{lbs}
\end{aligned}
$$

- Sensitivity of takeoff weight to payload weight:

$$
\begin{aligned}
& \frac{\partial W_{T O}}{\partial W_{P L}}=B W_{T O}\left(D-C(1-B) W_{T O}\right)^{-1} \\
& \frac{\partial W_{T O}}{\partial W_{P L}}=3.12
\end{aligned}
$$

This means, that for each pound of payload added, the airplane takeoff weight will have to be increased by $3.2 \mathrm{lbs}$. This assumes that the mission performance stays the same [44] Table 6.

- Sensitivity of takeoff weight to empty weight:

$$
\begin{aligned}
& \frac{\partial W_{T O}}{\partial W_{P L}}=B W_{T O}\left(10 \frac{\log _{10} W_{T O}-A}{B}\right)^{-1} \\
& \frac{\partial W_{T O}}{\partial W_{E}}=1.78
\end{aligned}
$$

This means, that for each pound of increase in empty weight, the takeoff weight must be in- creased by 1.78 lbs., to keep the mission performance the same [44].

- Factor F calculation:

$$
\begin{aligned}
& F=-B W_{T O}^{2}\left(C W_{T O}(1-B)-D\right)^{-1}\left(1+M_{r e s}\right) M_{f f} \\
& F=5573.85 \mathrm{lb} \\
& \text { - Sensitivity of takeoff weight to range: } \\
& \frac{\partial W_{T O}}{\partial R}=F_{C_{P}}\left(375 \eta_{P} L / D\right)^{-1} \\
& \frac{\partial W_{T O}}{\partial R}=1.23 \mathrm{lb} / \mathrm{nm}
\end{aligned}
$$

The significance of this partial is as follows. Suppose that the range in the mission specification is changed from 276.19 statues miles to 376.19 statues miles. The result just found indicates that this would require an increase in gross weight at takeoff of $(100)(1.23 \mathrm{lb} / \mathrm{nm})=123 \mathrm{lbs}$ [44].

- Sensitivity of takeoff gross weight to specific fuel consumption:

$$
\begin{aligned}
\frac{\partial W_{T O}}{\partial_{C_{P}}} & =F R\left(375 \eta_{P} L / D\right)^{-1} \\
\frac{\partial W_{T O}}{\partial_{C_{P}}} & =501.65 \mathrm{lb} / \mathrm{lb} / \mathrm{hp} / \mathrm{hr}
\end{aligned}
$$

The significance of this finding is as follows. Suppose the engine could be found with a $C_{P}$ of 0.5 instead 0.55 (Table 3 ) 7he takeoff gross weight could then be decreased by $(0.05)(501.65 \mathrm{lb} / \mathrm{lb} / \mathrm{hp} / \mathrm{hr})=25.08 \mathrm{lbs}$ [44].

- Sensitivity of takeoff gross weight to propeller efficiency:

$\frac{\partial W_{T O}}{\partial \eta_{P}}=-F R_{C_{P}}\left(375 \eta_{P}^{2} L / D\right)^{-1}$

$$
\frac{\partial W_{T O}}{\partial \eta_{P}}=-369.27 \mathrm{lb}
$$

The meaning of this finding is as follows. If the propeller efficiency $\eta_{P}$ could be increased from 0.8 to 0.82 (Table 3 ) the takeoff gross weights would decreased by $(0.02)(369.27 \mathrm{lbs})=7.38 \mathrm{lbs}$ [44].

- Sensitivity of takeoff gross weight to lift-todrag ratio:

$$
\frac{\partial W_{T O}}{\partial^{\frac{L}{D}}}=-F R_{C_{P}}\left(375 \eta_{P}(L / D)^{2}\right)^{-1}
$$

$\frac{\partial W_{T O}}{\partial^{\frac{L}{D}}}=-33.03 \mathrm{lbs}$ 


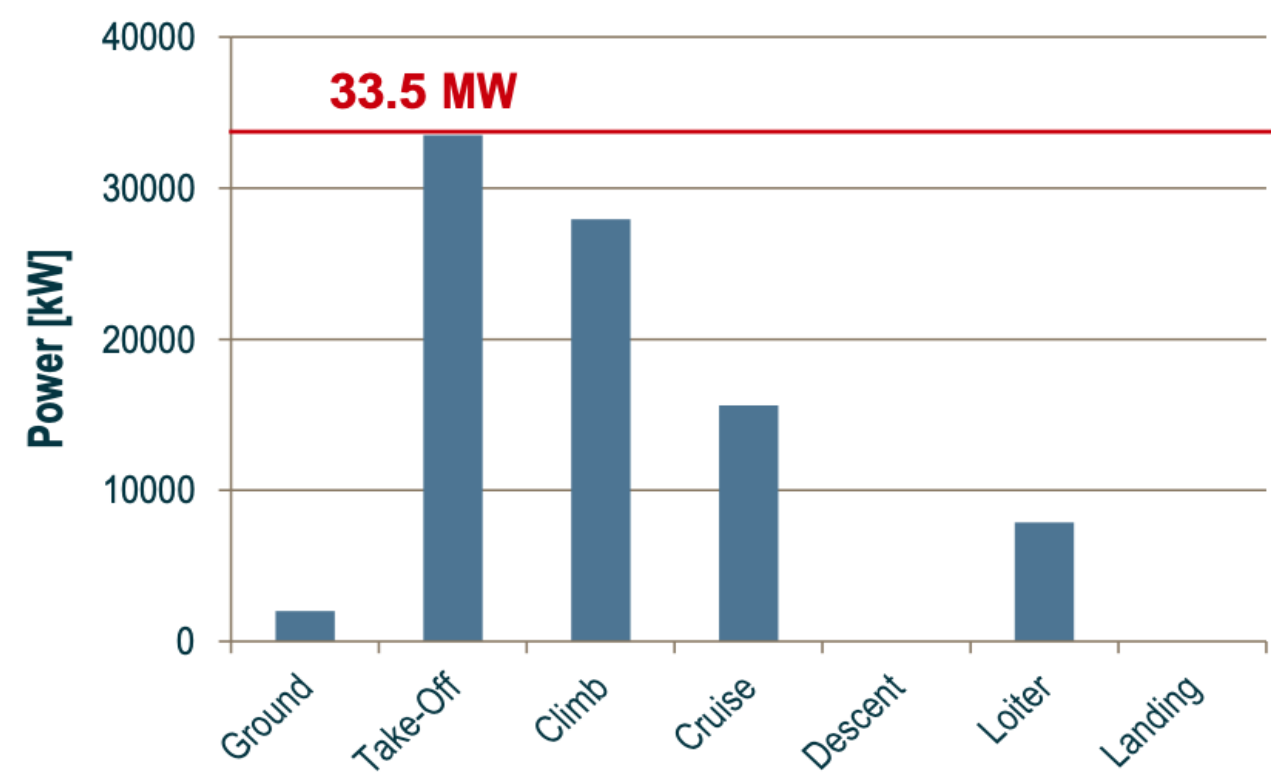

Flight Phase

Figure 17: Power demand of propulsion system.

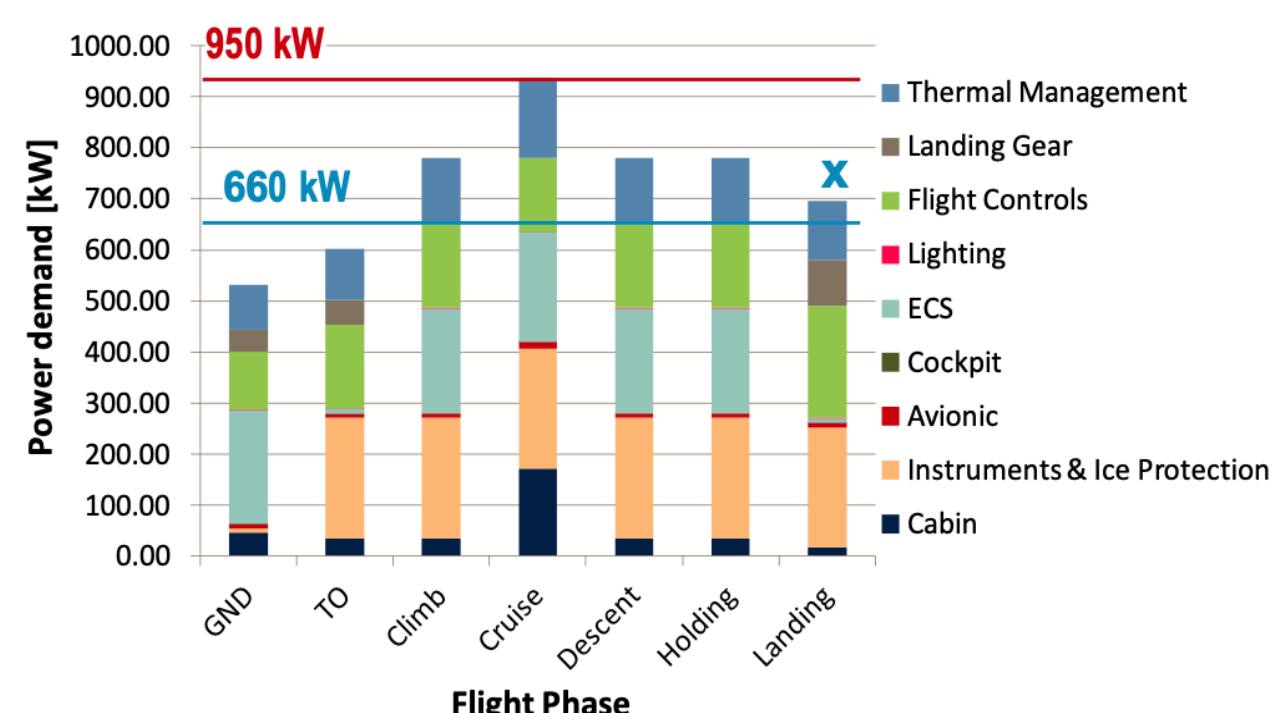

Figure 18: Power demand of subsystems.

This result means that if $L / D$ could be increased from 9 to 10 (Table 4) the takeoff gross weight would come down by $33.03 \mathrm{lbs}$. It comes as no surprise, that $L / D$ in a range dominated airplane has a powerful effect on gross weight [44].

Followed this, some considerations about the previous sensitivity study must be done. Assuming the electric aircraft proposed, the mission fuel weight is estimated under Jean Roskam's considerations [44]; where the responses of the mission fuel weight are assumed as the batteries weight and its systems involved. For more accurate future calculations is recommended to follow the Hepperle's methodology [22], knowing the exact batteries capabilities about power demand for several flight mission phases, Figure 17 and Figure 18 [45].

Next, a more complete sensitivity study is showed assuming a stable cruise speed of 160 knots, varying flight time, and in consequence, the flight range within the logical duration parameters of an air instruction class: Table 7.

\section{Comparative study of similar airplanes}

The baseline of electric aircraft is done about di- 
Table 7: Sensitivity studies responses.

\begin{tabular}{|l|l|l|l|}
\hline & $\begin{array}{l}\text { Flight time } \\
\text { of } \mathbf{1} \text { hour } \\
\text { with a flight } \\
\text { range of 184 } \\
\text { statute miles }\end{array}$ & $\begin{array}{l}\text { Flight time } \\
\text { of } \mathbf{1 . 5} \text { hours } \\
\text { with a flight } \\
\text { range of 276 } \\
\text { statute miles }\end{array}$ & $\begin{array}{l}\text { Flight time } \\
\text { of } \mathbf{2} \text { hours } \\
\text { with a flight } \\
\text { range of 368 } \\
\text { statute miles }\end{array}$ \\
\hline$\frac{\partial W_{T O}}{\partial W_{P L}}$ & 3.10 & 3.12 & 3.14 \\
\hline$\frac{\partial W_{T O}}{\partial W_{E}}$ & 1.78 & 1.78 & 1.78 \\
\hline$\frac{\partial W_{T O}}{\partial R}$ & 1.25 & 1.23 & 1.22 \\
\hline$\frac{\partial W_{T O}}{\partial C_{P}}$ & 338.73 & 501.65 & 660.32 \\
\hline$\frac{\partial W_{T O}}{\partial \eta_{P}}$ & -249.34 & -369.27 & -486.07 \\
\hline$\frac{\partial W_{T O}}{\frac{L}{D}}$ & -22.3 & -33.03 & -43.47 \\
\hline$\frac{2}{D}$ & & & \\
\hline
\end{tabular}
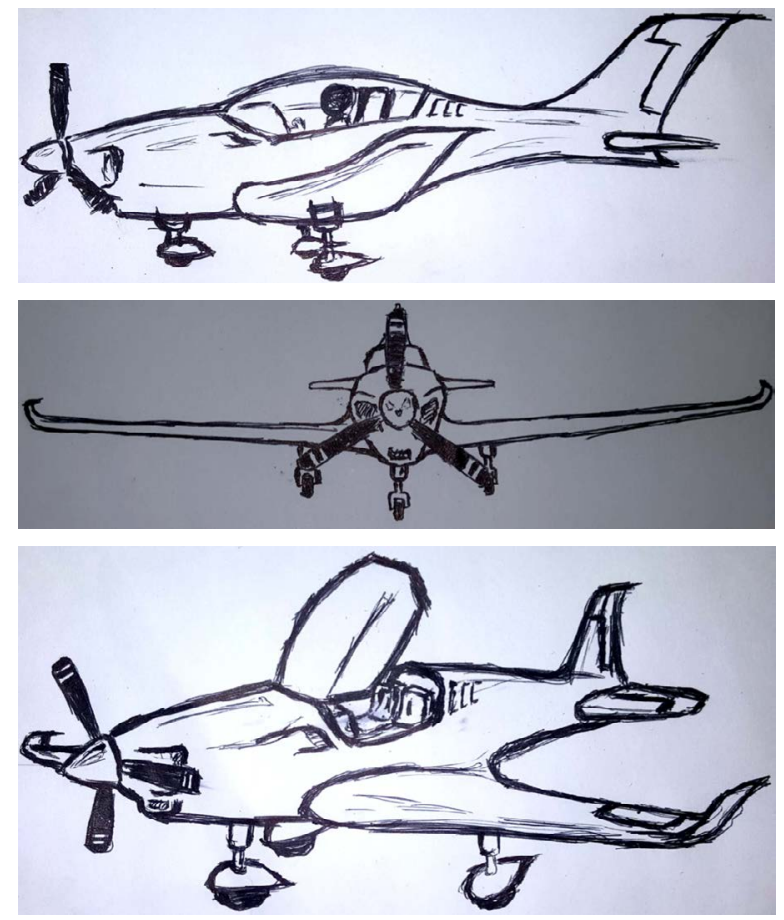

Figure 20: Preliminary sketch 2.

mensional and performance parameters, Table 8. With it will be possible a previous estimating about principal design requirements, getting any ideas about the main aircraft layout and the identification of significant changes with the sensitivity study if required $[46,47]$.

Thus, under the Table 8 information, it's correct to deduce the dimensional and performance averages for the electric aircraft preliminary sizing (Figure 19 and Figure 20), such:

- The main wing configurations are governed by the tapered, rectangular and mixed wing types, where tapered and rectangular wing type prevail, without forget that the mixed wing type could be a great alternative to allow high margins of performance. Similarly, the low wing location and a monoplane fixedwing are the trend, which under future aerodynamics predictions would help to choose the airfoil with a positive dihedral angle, a wingspan of 11.4 meters and aspect ratio of 11.8 under the Table 8 considerations.

- The tail configuration is governed by an aft conventional tail, where it isn't easy to deduct the attachment method, but in this stage, it's correct to assume a fixed tail attachment method.

Figure 19: Preliminary sketch 1.

- The propulsion system configuration is gov- 
Table 8: Base line of electric aircraft.

\begin{tabular}{|c|c|c|c|c|}
\hline $\begin{array}{l}\text { Aircraft } \\
\text { Pipistrel Alpha Electro G2 [48] }\end{array}$ & \multicolumn{2}{|c|}{ Dimensional parameters } & \multicolumn{2}{|c|}{ Performance parameters } \\
\hline Pipistrel Alpha Electro G2 [48] & $\begin{array}{l}\text { Span Wing: } \\
10.5 \mathrm{~m} \\
\text { Length: } 6.5 \mathrm{~m} \\
\text { Height: } 2.05 \mathrm{~m} \\
\text { Aspect Ratio: } \\
11.8\end{array}$ & $\begin{array}{l}\text { Fuselage: Side-by-side, } \\
\text { cabin. } \\
\text { Wing: Rectangular, high } \\
\text { wing, monoplane, fixed } \\
\text { wing. } \\
\text { Tail: T-tail, aft tail. } \\
\text { Engine: tractor (single- } \\
\text { engine) propeller-driven } \\
\text { Landing gear: Tricycle }\end{array}$ & $\begin{array}{l}\text { Max takeoff } \\
\text { weight: } 550 \mathrm{~kg} \\
\text { Payload weight: } \\
182 \mathrm{~kg} \\
\text { Stall Speed: } \\
70.3 \mathrm{~km} / \mathrm{h} \\
\text { Cruise Speed: } \\
157.42 \mathrm{~km} / \mathrm{h}\end{array}$ & $\begin{array}{l}\text { Max Speed: } \\
250 \text { km/h } \\
\text { Engine: } \\
\text { Pipistrel PEM } \\
60 \mathrm{MVLC} ; 60 \\
\text { kW power } \\
\text { Endurance: } 1 \\
\text { hour } \\
\text { Cruise Range: } \\
138.9 \text { km }\end{array}$ \\
\hline & $\begin{array}{l}\text { Span Wing: } \\
14.5 \mathrm{~m} \\
\text { Length: } 6.61 \mathrm{~m} \\
\text { Height: } 2.45 \mathrm{~m} \\
\text { Aspect Ratio: }\end{array}$ & $\begin{array}{l}\text { Fuselage: Side-by-side, } \\
\text { cabin. } \\
\text { Wing: Rectangular, } \\
\text { Tapered, high wing, } \\
\text { monoplane, fixed wing. } \\
\text { Tail: T-tail, aft tail. } \\
\text { Engine: tractor (single- } \\
\text { engine) propeller-driven } \\
\text { Landing gear: Tricycle }\end{array}$ & $\begin{array}{l}\text { Max takeoff } \\
\text { weight: } 500 \mathrm{~kg} \\
\text { Payload weight: } \\
162 \mathrm{~kg} \\
\text { Stall Speed: } 73 \\
\mathrm{~km} / \mathrm{h} \\
\text { Cruise Speed: } \\
120 \mathrm{~km} / \mathrm{h}\end{array}$ & $\begin{array}{l}\text { Max Speed: } \\
160 \text { km/h } \\
\text { Engine: } \\
\text { A37K154; } 30 \\
\text { kW power } \\
\text { Endurance: } 1 \\
\text { hour } \\
\text { Cruise Range: }\end{array}$ \\
\hline & $\begin{array}{l}\text { Span Wing: } \\
8.13 \mathrm{~m} \\
\text { Length: } 6.45 \mathrm{~m} \\
\text { Height: } 2.28 \mathrm{~m} \\
\text { Aspect Ratio: }\end{array}$ & $\begin{array}{l}\text { Fuselage: Side-by-side, } \\
\text { cockpit. } \\
\text { Wing: Rectangular, low } \\
\text { wing, monoplane, fixed } \\
\text { wing. } \\
\text { Tail: Conventional, aft tail. } \\
\text { Engine: tractor (single- } \\
\text { engine) propeller-driven } \\
\text { Landing gear: Tricycle }\end{array}$ & $\begin{array}{l}\text { Max takeoff } \\
\text { weight: } 850 \mathrm{~kg} \\
\text { Payload weight: } \\
200 \mathrm{~kg} \\
\text { Stall Speed: } \\
\text { Cruise Speed: }\end{array}$ & $\begin{array}{l}\text { Max Speed: } \\
\text { Engine: } 90 \mathrm{~kW} \\
\text { power } \\
\text { Endurance: } \\
1.5 \text { hours } \\
\text { Cruise Range: }\end{array}$ \\
\hline lyer 2 [51] & $\begin{array}{l}\text { Span Wing: } \\
11.58 \mathrm{~m} \\
\text { Length: } \\
\text { Height: } \\
\text { Aspect Ratio: }\end{array}$ & $\begin{array}{l}\text { Fuselage: Side-by-side, } \\
\text { cockpit. } \\
\text { Wing: Rectangular, low } \\
\text { wing, monoplane, fixed } \\
\text { wing. } \\
\text { Tail: Conventional, aft tail. } \\
\text { Engine: tractor (single- } \\
\text { engine) propeller-driven } \\
\text { Landing gear: Tricycle }\end{array}$ & $\begin{array}{l}\text { Max takeoff } \\
\text { weight: } 862 \mathrm{~kg} \\
\text { Payload weight: } \\
200 \mathrm{~kg} \\
\text { Stall Speed: } \\
\text { Cruise Speed: }\end{array}$ & $\begin{array}{l}\text { Max Speed: } \\
250 \mathrm{~km} / \mathrm{h} \\
\text { Engine: } \\
\text { Siemens } \\
\text { SP70D; } 90 \mathrm{~kW} \\
\text { power } \\
\text { Endurance: } \\
3.5 \text { hours } \\
\text { Cruise Range: }\end{array}$ \\
\hline
\end{tabular}




\begin{tabular}{|c|c|c|c|c|}
\hline gnus eFusion & $\begin{array}{l}\text { Span Wing: } \\
8.3 \mathrm{~m} \\
\text { Length: } 6.62 \mathrm{~m} \\
\text { Height: } 2.4 \mathrm{~m} \\
\text { Aspect Ratio: }\end{array}$ & $\begin{array}{l}\text { Fuselage: Side-by-side, } \\
\text { cockpit. } \\
\text { Wing: Tapered, low wing, } \\
\text { monoplane, fixed wing. } \\
\text { Tail: Conventional, aft tail. } \\
\text { Engine: tractor (single- } \\
\text { engine) propeller-driven } \\
\text { Landing gear: Tricycle }\end{array}$ & $\begin{array}{l}\text { Max takeoff } \\
\text { weight: } 600 \mathrm{~kg} \\
\text { Payload weight: } \\
190 \mathrm{~kg} \\
\text { Stall Speed: } \\
64.8 \mathrm{~km} / \mathrm{h} \\
\text { Cruise Speed: } \\
185 \mathrm{~km} / \mathrm{h}\end{array}$ & $\begin{array}{l}\text { Max Speed: } \\
313 \mathrm{~km} / \mathrm{h} \\
\text { Engine: } \\
\text { Siemens } \\
\text { SP55D; } 60 \mathrm{~kW} \\
\text { power } \\
\text { Endurance: } 1 \\
\text { hour } \\
\text { Cruise Range: }\end{array}$ \\
\hline Yuneec E & $\begin{array}{l}\text { Span Wing: } \\
13.8 \mathrm{~m} \\
\text { Length: } 6.98 \mathrm{~m} \\
\text { Height: } \\
\text { Aspect Ratio: }\end{array}$ & $\begin{array}{l}\text { Fuselage: Side-by-side, } \\
\text { cabin. } \\
\text { Wing: Tapered, } \\
\text { rectangular, high wing, } \\
\text { monoplane, fixed wing. } \\
\text { Tail: V-tail, aft tail. } \\
\text { Engine: tractor (single- } \\
\text { engine) propeller-driven } \\
\text { Landing gear: Tricycle }\end{array}$ & $\begin{array}{l}\text { Max takeoff } \\
\text { weight: } 470 \text { kg } \\
\text { Payload weight: } \\
177 \text { kg } \\
\text { Stall Speed: } 70 \\
\text { km/h } \\
\text { Cruise Speed: } \\
96.5 \mathrm{~km} / \mathrm{h}\end{array}$ & $\begin{array}{l}\text { Max Speed: } \\
152.88 \text { km/h } \\
\text { Engine: } \\
\text { Yuneec Power } \\
\text { Drive 40; } 40 \\
\text { kW power } \\
\text { Endurance: } \\
2.5 \text { hours } \\
\text { Cruise Range: } \\
227 \text { km }\end{array}$ \\
\hline Diamo & $\begin{array}{l}\text { Span Wing: } \\
16 \mathrm{~m} \\
\text { Length: } 7.1 \mathrm{~m} \\
\text { Height: } 1.7 \mathrm{~m} \\
\text { Aspect Ratio: }\end{array}$ & $\begin{array}{l}\text { Fuselage: Side-by-side, } \\
\text { cockpit. } \\
\text { Wing: Tapered, low wing, } \\
\text { monoplane, fixed wing. } \\
\text { Tail: T-tail, aft tail. } \\
\text { Engine: tractor (single- } \\
\text { engine) propeller-driven } \\
\text { Landing gear: Tricycle }\end{array}$ & $\begin{array}{l}\text { Max takeoff } \\
\text { weight: } 800 \mathrm{~kg} \\
\text { Payload weight: } \\
\text { Stall Speed: } \\
\text { Cruise Speed: }\end{array}$ & $\begin{array}{l}\text { Max Speed: } \\
\text { Engine: } \\
\text { Siemens; } 70 \\
\text { kW power } \\
\text { Endurance: } \\
\text { Cruise Range: }\end{array}$ \\
\hline & $\begin{array}{l}\text { Span Wing: } \\
8 \mathrm{~m} \\
\text { Length: } 7.5 \mathrm{~m} \\
\text { Height: } 2.6 \mathrm{~m} \\
\text { Aspect Ratio: }\end{array}$ & $\begin{array}{l}\text { Fuselage: Tandem, } \\
\text { cockpit. } \\
\text { Wing: Tapered, low wing, } \\
\text { monoplane, fixed wing. } \\
\text { Tail: Conventional, aft tail. } \\
\text { Engine: tractor (single- } \\
\text { engine) propeller-driven } \\
\text { Landing gear: Tail gear }\end{array}$ & $\begin{array}{l}\text { Max takeoff } \\
\text { weight: } 820 \mathrm{~kg} \\
\text { Payload weight: } \\
200 \mathrm{~kg} \\
\text { Stall Speed: } \\
101.86 \mathrm{~km} / \mathrm{h} \\
\text { Cruise Speed: }\end{array}$ & $\begin{array}{l}\text { Max Speed: } \\
337.5 \text { km/h } \\
\text { Engine: } \\
\text { Siemens } \\
\text { SP260D; } 260 \\
\text { kW power } \\
\text { Endurance: } \\
20 \text { minutes at } \\
\text { max power } \\
\text { Cruise Range: }\end{array}$ \\
\hline
\end{tabular}

erned by an electric single-engine system in front of the nose with the tractor type propeller configuration. This electrical engine should allow a stall speed of $76 \mathrm{~km} / \mathrm{h}$, a cruise speed of $140 \mathrm{~km} / \mathrm{h}$ and a maximum speed of $244 \mathrm{~km} / \mathrm{h}$ developing a power of $87.5 \mathrm{~kW}$ for 1.5 hours of flight endurance and $183 \mathrm{~km}$ of flight range.

- The fuselage configuration is governed by the side-by-side seat alternative and cockpit type door configuration. It isn't easy to deduct the pressure system method, but it is correct to assume an aircraft without this system in this design stage. The fuselage length average is $6.8 \mathrm{~m}$ with a height of $2.2 \mathrm{~m}$, these dimensions allow a takeoff weight average of 682.6 $\mathrm{kg}$ for a payload weight of $187.3 \mathrm{~kg}$; thus, supported on Table 8 [48-55] information, the 


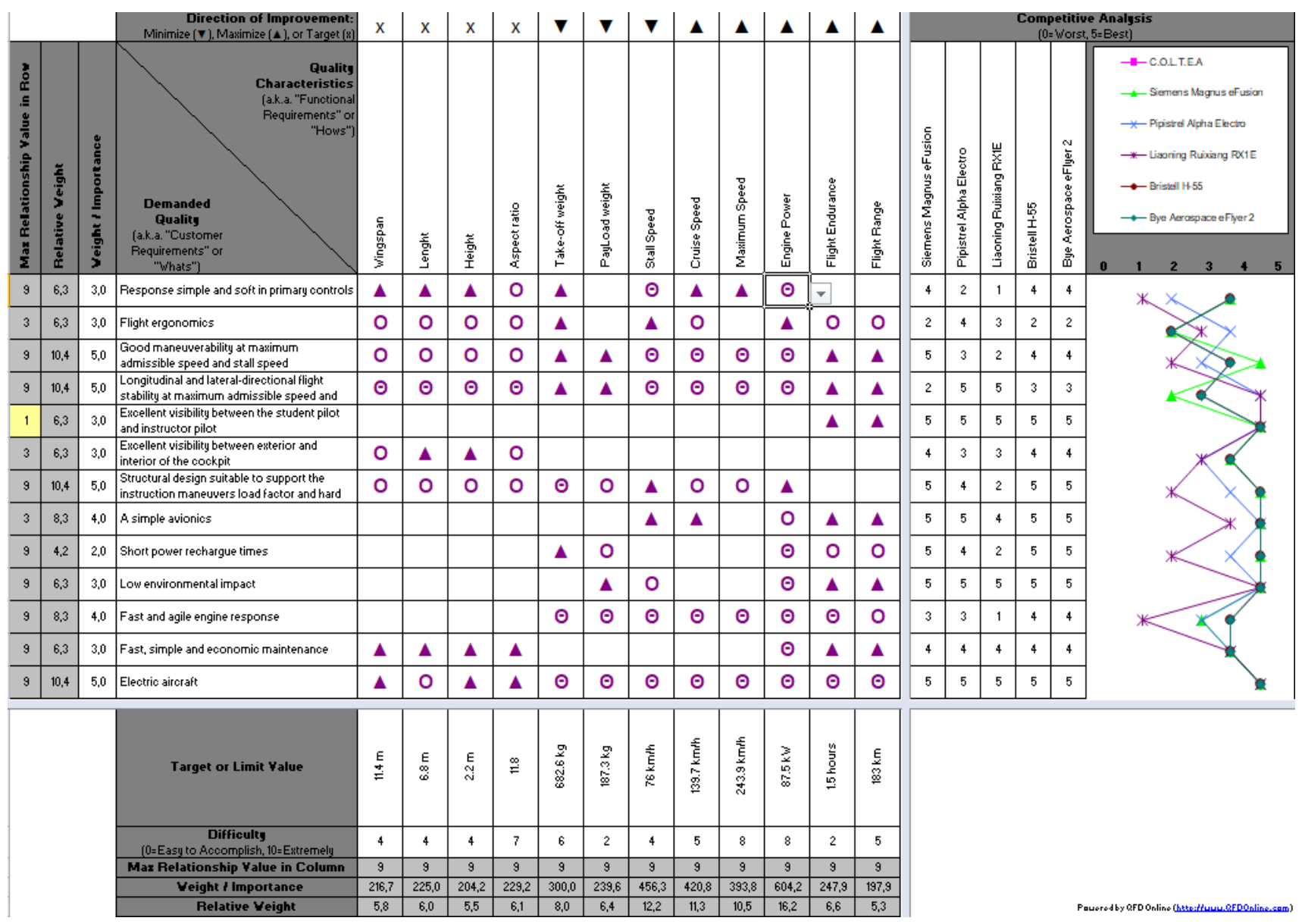

Figure 21: Electric training aircraft QFD matrix.

landing gear configuration would be a tricycle type with a fixed mechanism.

- Thus, the preliminary sketches of the electric training aircraft will be:

\section{Quality function deployment}

Apropos of the design requirements necessary to achieve manufacture an electrical training aircraft, it is convenient to transform those qualitative demands into quantitative parameters as it is the comparative study done previously. The QFD matrix helps to do this work easier.

Thus, with the parameters found in the comparative study are resolved by the QFD matrix for the electric training aircraft proposed, Figure 21. In the competitive analysis, the eflyer 2 and Bristell $\mathrm{H}-55$ are the airplanes with the highest score in satisfying the design requirements, so the manufacture and design could be directed about the importance of the engine power functional requirement under the authors' considerations, without ignoring the dimensional requirements.
Finally, it is correct to consider that in the preliminary and detailed design phase the maneuverability, stability, structural resistance, and the aircraft electrification are the most important requirements to considerer and predict future necessities about industrial, social and economic capabilities to carry out this task.

\section{Services and Capabilities Required for Co- lombia}

In the act of pretending to offer an aeronautical product with high standards of design, manufacturing, pre-assembly and final assembly, it is necessary to understand the importance of each agent involved in the manufacturing line allowing a fast, economic and reliable processes.

As the first aspect, there are the airworthiness mandatory rules that allow being clear about aircraft type with its specifications description without incurring in confusion to be aware of the design constraints. In the case of an electric instruction aircraft, the American norm FAR 23 [56], with 
its Colombian version of RAC 23 [57], applies the airworthiness standards for civil aircraft and/or general aviation, especially in the certification processes of any aeronautical product used based on the validation of a type certificate by the UAEAC Certification Group of aeronautical Products, or by SECAD ${ }^{37}$ section within the SICAD $^{38}$ agreement.

Within this work plan, Colombia could obtain the benefit of allowing itself to advance in the strengthening of the aeronautical products certifications and supply chains, establishing opportunities for the aeronautical industry develop, together with the complementary sectors to it. It is essential to take advantage of the Defense sector experience and its works done, who have encouraged Colombian aeronautical development as a solution to obstacles encountered with foreign companies in charge of supply their military aircraft, based on clusters and national companies, making aeronautical products with high-quality standards [58-60]. This is how these efforts can be oriented to the national aviation industry progress to meet the requirements together with a technology and experience transfer, not only in the military aviation, but also in civil aviation, whose products could be duly certified, applying in the manufacture of civil aeronautics parts the military air standards.

Alternating, you should not lose sight of the work and support that must be provided by the public sector through MinDefensa, MinCiencia, MinComercio, ProColombia, ANDI ${ }^{39}$, Chambers of Commerce, DNP ${ }^{40}, F A C$, and the private sector through ACOPAER, CAESCOL, among other. This is to contribute to the aeronautic sector development, enhancing growth in the national aeronautic and aerospace companies (such CIAC) to rival with international companies such as EMBRAER (Brazil), Boeing (EE.UU) and Airbus (Europe) [61]. The last information is important with the inclusion of the academy, incentivizing aeronautic events such as F-AIR $^{41}$, EXPODEFENSA ${ }^{42}$, Aerospace Industry Fair CAMAN $^{43}$, among other, that together with national strategic plans (such as PEICA, PEDSAA and Foro Plan Estratégico Aeronáutico 2018-2030) could provide the appropriate scenario to identify, strengthen and encourage public policies, suppliers, allies, products, and important developments for the Colombian aeronautical industry can improve its ability to offer aeronautical services Worldwide.

On the other hand, a very important aspect is the start-up of an aeronautical production plant with the task of manufacturing, pre-assembling and assembling. It must keep its competitiveness and its staff with a vision focused on manufacturing projects, modernization, modification, and repair of aeronautical parts within Colombia, plus the latest technological and legal trends with the high production and quality standards to consolidate trained personnel in aeronautical processes. In this way, to increase the value and number of goods and services offered, the production, human resources, raw materials, inputs and infrastructure should be evaluated based on risk matrices that allow identifying which areas should be improved, strengthened and/or changed.

Likewise, it is appropriate to consider the review of national regulation and public policies which allows access to new markets as a basis for the promotion of the national social and economic development; the goal is to achieve the internationalizing aeronautic sector reducing costs and times of projects transaction for that boosting the competitiveness and the promotion of entrepreneurship. The best example to keep in mind is the production process (by FAC and CIAC) of the Calima T-90 training aircraft with the UNE-EN 9100 standard, which in compliance with international standards and treaties ensures the quality of the design processes, modifications, manufacturing, pre-assembly and final assembly. In this way, the aircraft factory and its suppliers must have the government solid support in the implementation of aeronautical codes with clear laws and an academy interaction generating legal instruments to stimulate and regulate the aeronautic sector; this mutual work will strengthen the participation mechanisms development that leads to aerospace success with clear and precise methodologies in national needs.

Together with production plant infrastructure, interdisciplinary groups should strengthen the goal of incorporating the best methods, tools, and processes to address the electric aircraft manufacture with the requirements given by customers, users and investors. All the design and manufacturing capabilities and knowledge should be included through the humans, hardware and software components to meet the regulatory and technical limitations and assure productivity, affordability, reliability, usability, supportability, detectability, availability and operability of aeronautic goods and 
services offer, managing to position the Colombian aeronautical and aerospace sector as a competitive and sustainable industry.

Finally, the work team involved must work concerning a schedule of activities that includes a design stage, a development stage, a production stage, a support stage and an availability stage. In these processes, the design phases don't only focus on the conceptual design, preliminary design, and detailed design, but a fourth phase of tests and evaluations should be added. The conception, design, production, operation, and maintenance must be influenced by the technical, economic, political, organizational, financial and regulatory factor, where the aircraft engineering, as a system, requires the best methods, tools, and processes; it should be focused on the production plan and the maintenance support for future users, so the aircraft traceability could be guaranteed to allow large viability margins in the manufacture of a Colombian electric training aircraft.

\section{Conclusions}

- On the previous aircraft manufacture experience, and configurations and design requirements identified, the best aerodynamic, dimensional and structural configuration must be evaluated by specialized aeronautical software. From the preliminary sizing proposed, it is convenient for others wing, fuselage, propulsion, tail and landing gear configurations should not be discarded following the innovation and entrepreneurship guidelines.

- The aircraft electrification leads to the addition of electrical energy storage systems. Many advances need to be made from the reliability of power electronics, where their sizing is a critical issue, and its optimization is mandatory to minimize the take-off weight as an essential requirement.

- The electric aircraft could achieve high reliability, easy maintenance, high support potential, and a decrease of weight, volume, and system complexity. Thus, it will have a reduction of maintenance cost, fewer unexpected delays due to failures, enhanced competitiveness and production improvement. These advantages should not be limited to aircraft; conversely, other sustainable transport systems should also take advantage of these advances.

- The aircraft maintainability and its impact on the operational cost are difficult to evaluate now. Based on the experience of the CALIMA T-90 program, it is necessary for involving mechanics and technicians in the design process to review the mock-ups and prototypes to obtain feedback about the maintainability and the infrastructure necessary.

- The detailed design phase should reside in energy rationalization and management capacity to allow increasing the system availability. Nevertheless, further studies are needed to identify an optimized aircraft detailed size, overall electric system efficiency and thermal management.

- The Academy-Government-Industry unification is necessary in allowing the science, innovation and entrepreneurship inclusion. Thus, the electric aircraft manufacture will provide an efficient product about the Colombia operational needs that it would be appropriate for public and private aeronautical institutions. All this would help to lead to a sustainable commercial aviation as an alternative for the aeronautic and aerospace Colombian industry development.

\section{References}

1. (2020) About the journal scope. Environmental Research Letters ERL, IOP Science.

2. Crespo Cristina (2019) Los impactos de las emisiones de la aviación en la calidad del aire son mayores que el clima. National Geographic.

3. Grobler C, Wolfe PJ, Dasadhikari K, Dedoussi IC, Allroggen $F$, et al. (2019) Marginal climate and air quality cost of aviation emissions. Environmental Research Letters 14: 114031.

4. (2016) Proyección de demanda de combustibles líquidos en Colombia. Unidad de Planeación Minero Energética.

5. (2019) Plan Energético Nacional 2020-2050. Unidad de Planeación Minero Energético.

6. (2020) E-Fan X: A giant leap towards zero-emission flight. AIRBUS.

7. (2020) About the foundation. Solar Impulse Foundation.

8. Bernabeo RA, Piancastelli L, Malik ZH, Al Azad A, Ya- 
seen JA (2018) Study and testing of a green trainer to transform small general aviation aircraft for training into a no-emission aerial vehicles. Advances in Science and Engineering Technology International Conferences (ASET), 1-3.

9. (2020) Tesla Model S. Tesla, Inc.

10.(2020) ABB FIA Formula E championship. ABB Formula E.

11.(2020) FIM Enel MotoE world cup. Moto GP.

12.(2020) FIA Formula One World Championship. Formula 1.

13.Diario Renovables (2018) Noruega lidera el camino para convertirse en el primer país $100 \%$ eléctrico del mundo en movilidad.

14.Mariano E (2018) Noruega vuela alto; apunta a la electrificación aérea para 240.

15. Rosero JA, Ortega JA, Aldabas E, Romeral LARL (2007) Moving towards a more electric aircraft. IEEE Aerospace and Electronic Systems Magazine 22: 3-9.

16.(2019) Proyección de la demanda de energía eléctrica y potencia máxima en Colombia. Unidad de Planeación Minero Energética.

17.(2016) Proyección de la demanda de energía eléctrica y potencia máxima en Colombia. Unidad de Planeación Minero Energética.

18.Brelje BJ, Martins JR (2019) Electric, hybrid and turboelectric fixed-wing aircraft: A review of concepts, models, and design approaches. Progress in Aerospace Sciences 104: 1-19.

19.Stoll AM, Bevirt J, Moore MD, Fredericks WJ, Borer NK (2014) Drag reduction through distributed electric propulsion. 14th AIAA aviation technology, integration, and operations conference, 2851.

20.Brooks C, Salgueiro S (2017) Design space investigation for a small electric general aviation airplane. 55th AIAA Aerospace Sciences Meeting, 1181.

21.Naru R, German B (2018) Maintenance considerations for electric aircraft and feedback from aircraft maintenance technicians. Aviation Technology, Integration, and Operations Conference, 3053.

22. Hepperle M (2012) Electric flight-potential and limitations.

23.Gohardani AS, Doulgeris G, Singh R (2011) Challenges of future aircraft propulsion: A review of distributed propulsion technology and its potential application for the all-electric commercial aircraft. Progress in Aerospace Sciences 47: 369-391.
24.(2018) Foro Plan Estratégico Aeronáutico 20182030. Unidad Administrativa Especial Aeronáutica Civil (UAEAC), Colombia.

25.(2013) Avión calima T-90. Fuerza Aérea Colombiana.

26.Sadraey MH (2012) Aircraft design: A systems engineering approach. John Wiley \& Sons, USA.

27.Castellanos Sanabria YA, Rodríguez Pirateque GW (2019) Estudio de las cualidades de vuelo y manejo de una aeronaves tipo planeador para instrucción. Ciencia y Poder Aéreo 14: 162-179.

28.Cook MV (2012) Flight dynamics principles: A linear systems approach to aircraft stability and control. Butterworth-Heinemann.

29. Roskam J (1998) Airplane flight dynamics and automatic flight controls. DARcorporation.

30.(2017) AVL Overview. MIT Education.

31.(2020) Advanced Aircraft Analysis: Overview. DAR Corporation.

32.(2019) Break-in (mechanical run-in). Wikipedia: The Free Encyclopedia.

33.Antcliff KR, Guynn MD, Marien T, Wells DP, Schneider SJ, et al. (2016) Mission analysis and aircraft sizing of a hybrid-electric regional aircraft. 54th AIAA Aerospace Sciences Meeting, 1028.

34.Anton F, Siemens AG (2019) eAircraft: Hybrid-elektrische Antriebe für Luftfahrzeuge. SIEMENS.

35.Barufaldi G, Morales M, Silva RG (2019) Energy optimal climb performance of electric aircraft. AIAA Scitech, 0830 .

36. Nelson RC (1998) Flight stability and automatic control. ( $\left.2^{\text {nd }} e d n\right)$, WCB/McGraw Hill, New York, USA.

37. Roskam J, Lan CTE (1997) Airplane aerodynamics and performance. DARcorporation.

38. Chen J, Wang C, Chen J (2018) Investigation on the selection of electric power system architecture for future more electric aircraft. IEEE Transactions on Transportation Electrification 4: 563-576.

39. Wheeler P (2016) Technology for the more and all electric aircraft of the future. IEEE International Conference on Automatica, 1-5.

40.Sarlioglu B, Morris CT (2015) More electric aircraft: Review, challenges, and opportunities for commercial transport aircraft. IEEE transactions on Transportation Electrification 1: 54-64.

41.Saenger P, Deschinkel K, Devillers N, Pera MC (2015) An optimal sizing of electrical energy storage system for an accurate energy management in an aircraft. 
IEEE Vehicle Power and Propulsion Conference, 1-6.

42.Siemens (2017) Refueling an electric aircraft.

43. Heinrich MT, Kelch F, Magne P, Emadi A (2015) Regenerative braking capability analysis of an electric taxiing system for a single aisle midsize aircraft. IEEE Transactions on Transportation Electrification 1: 298-307.

44. Roskam J (1985) Airplane design. DARcorporation.

45. Isikveren AT (2013) Future of [More] Electrical Aircraft. ICAS Biennial Workshop.

46. Raymer D (2012) Aircraft design: A conceptual approach. American Institute of Aeronautics and Astronautics, Inc.

47.Jenkinson LR, Marchman J (2003) Aircraft design projects: For engineering students. Elsevier.

48.(2020) Alpha Electro. PIPISTREL.

49.(2020) Ruixiang two-seater all-electric light-sport aircraft Liaoning Ruixiang RX1E. Rui-xiang General Aircraft Manufacturing Co, Ltd.

50.(2020) Electric Propulsion Systems (EPS). H55.

51.(2020) eFlyer 2. Bye Aerospace.
52.(2020) eFusion. Magnus Aircraft.

53.(2020) The Yuneec E430. YUNEEC.

54.(2011) Diamond Aircraft. Diamond DA36 E-Star.

55.(2020) Extra aircraft. Extra 300 LE.

56.(2009) Part 23 - Small airplane certification process study: Recommendations for general aviation for the next 20 years. Federal Aviation Administration, FAA.

57.(2015) RAC 23 - Estándares de aeronavegabilidad: Aviones de categoría normal, utilitaria, acrobática y commuter. Unidad Administrativa Especial de Aeronáutica Civil, UAEAC.

58. (2018) Plan estratégico para el desarrollo del sector aeronáutico y aeroespacial. ACOPAER, Mindefensa, Fuerza Aérea Colombiana, SECAD.

59.(2017) Plan estratégico de la industria colombiana aeroespacial. ACOPAER.

60.Colciencias (2019) La fuerza Aérea Colombiana fortalece su sistema de ciencia, tecnología e innovación.

61.Zapata AFB (2017) Análisis de clústeres aeronáuticos referentes para el desarrollo del clúster aeroespacial colombiano. Ciencia y Poder Aéreo12: 36-58. 